Prepared for the U.S. Department of Energy

under Contract DE-AC05-76RL01830

\title{
Demonstration Assessment of Light-Emitting Diode (LED) Residential Downlights and Undercabinet Lights in the Lane County Tour of Homes, Eugene, Oregon
}

MK Ton

TL Gilbride

EE Richman

October 2008

Pacific Northwest

NATIONAL LABORATORY

Proudly Operated by Battelle Since 1965 
This report was prepared as an account of work sponsored by an agency of the United States Government. Neither the United States Government nor any agency thereof, nor Battelle Memorial Institute, nor any of their employees, makes any warranty, express or implied, or assumes any legal liability or responsibility for the accuracy, completeness, or usefulness of any information, apparatus, product, or process disclosed, or represents that its use would not infringe privately owned rights. Reference herein to any specific commercial product, process, or service by trade name, trademark, manufacturer, or otherwise does not necessarily constitute or imply its endorsement, recommendation, or favoring by the United States Government or any agency thereof, or Battelle Memorial Institute. The views and opinions of authors expressed herein do not necessarily state or reflect those of the United States Government or any agency thereof.

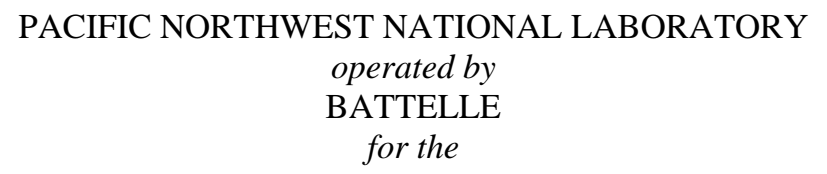

UNITED STATES DEPARTMENT OF ENERGY

under Contract DE-AC06-76RL01830

Printed in the United States of America

Available to DOE and DOE contractors from the Office of Scientific and Technical Information, P.O. Box 62, Oak Ridge, TN 37831-0062;

ph: (865) 576-8401

fax: (865) 576-5728

email: reports@adonis.osti.gov

Available to the public from the National Technical Information Service, U.S. Department of Commerce, 5285 Port Royal Rd., Springfield, VA 22161

ph: (800) 553-6847

fax: (703) 605-6900

email: orders@ntis.fedworld.gov

online ordering: http://www.ntis.gov/ordering.htm 


\section{Demonstration Assessment} of Light-Emitting Diode (LED) Residential Downlights and Undercabinet Lights in the Lane County Tour of Homes, Eugene, Oregon

Final Report prepared in support of the U.S. DOE Solid-State Lighting Technology Demonstration GATEWAY Program

Study Participants:

Pacific Northwest National Laboratory

U.S. Department of Energy

Energy Trust of Oregon

Lane County Home Builders Association

Future B Homes

\section{MK Ton}

EE Richman

TL Gilbride

October 2008

Prepared for the U.S. Department of Energy under Contract DE-AC05-76RL01830

Pacific Northwest National Laboratory

Richland, Washington 99352 


\section{Preface}

This document is a report of observations and results obtained from a lighting demonstration project conducted under the U.S. Department of Energy (DOE) SSL GATEWAY Demonstration Program. The program supports demonstrations of high-performance solid-state lighting (SSL) products in order to develop empirical data and experience with in-the-field applications of this advanced lighting technology. The program seeks to demonstrate SSL products in applications that save energy, are cost effective, and maintain or improve light levels in the tested lighting application. The DOE GATEWAY Demonstration Program focuses on providing a source of independent, third-party data for use in decision-making by lighting users and professionals; this data should be considered in combination with other information relevant to the particular site and application under examination. Each GATEWAY Demonstration compares one SSL product against the incumbent technology used in that location. Depending on available information and circumstances, the SSL product may also be compared to alternate lighting technologies. Though products demonstrated in the GATEWAY program have been prescreened and tested to verify their actual performance, DOE does not endorse any commercial product or in any way guarantee that users will achieve the same results through use of these products. 


\section{Executive Summary}

In August 2008 the Pacific Northwest National Laboratory (PNNL) conducted a light-emitting diode (LED) residential lighting demonstration project for the U.S. Department of Energy (DOE), Office of Building Technologies, as part of DOE's Solid-State Lighting (SSL) Technology Demonstration GATEWAY Program. Two lighting technologies, an LED replacement for lamps (bulbs) in downlights and an LED undercabinet lighting fixture, were evaluated in the demonstration which was conducted in two homes built for the 2008 Tour of Homes in Eugene, Oregon. The homes were built by the Lane County Home Builders Association (HBA) and Future B Homes. The Energy Trust of Oregon (ETO) also participated in the demonstration project.

The LED downlight product is called the LR6; it was developed by LED Lighting Fixtures Corporation (LLF) and is sold by Cree LED Lighting Solutions as a replacement for incandescent, compact fluorescent, and halogen lamps in recessed can downlights. It is a unique, integrated module with its own optics, trim, heat sink, and screw (or GU-24) base designed to allow the entire product to be installed in existing recessed downlight fixtures. The second product evaluated was Philips' eW® Profile Powercore undercabinet fixture, which was designed to mount under kitchen cabinets to illuminate the countertop and backsplash surfaces.

Quantitative and qualitative measurements of light performance and electrical power usage were taken at each site before and after initially installed halogen and incandescent lamps were replaced with the LED products. Energy savings and simple paybacks were calculated and builders who toured the homes were surveyed for their responses to the LED products.

The LED downlight product drew 12 Watts of power, reducing energy use by $82 \%$ compared to a 65W incandescent reflector lamp and by $84 \%$ compared to a $75 \mathrm{~W}$ halogen reflector lamp. The LED undercabinet fixture drew 10 watts, cutting energy use by $83 \%$ to $90 \%$ compared to a halogen product, which was tested at two power settings - a low power setting that drew 60 watts and a high power setting that drew 105 watts.

The LED downlights consistently provided more light than the halogen and incandescent lamps in horizontal illuminance measurements at counter height and floor level. They also outperformed in vertical illuminance measurements taken on the walls, indicating better lateral dispersion of the light. The undercabinet fixture's light output was midway between the low and high power halogen undercabinet fixture light outputs (35.8 foot candle versus $13.4 \mathrm{fc}$ and $53.4 \mathrm{fc}$ ) but it produced a more uniform light (max/min ratio of 7.0 versus 10.8 ).

The measured color correlated temperature (CCT) of the LED downlights correlated well with the CCT of the halogen and incandescent lights ( $2675 \mathrm{~K}$ vs. $2700 \mathrm{~K}$ ). The color rendering of the LED downlight also correlated well at 92 CRI compared to 100 CRI for the halogen and incandescent lamps. The LED undercabinet fixture had measures of $2880 \mathrm{~K}$ CCT and 71 CRI compared to the $2700 \mathrm{~K}$ and 100 CRI scores for the halogen undercabinet fixture.

Builders who toured the homes were asked to complete a written survey regarding their perceptions of the light quality. They gave the LED downlight high marks for brightness and most felt the LEDs 
were the same as or an improvement over the halogen and incandescent lamps in terms of shadows and glare. The majority gave the LED products high marks for overall visibility and improvement in home appearance and surprisingly a high number said they felt the LED products improved the homes' value (83\% said this about the downlight and 75\% said this about the undercabinet fixture).

The dimming performance of the LED downlight product was also evaluated because LEDs are anticipated to have better dimming capability than other high-efficiency downlight alternatives, namely CFL R-lamps. It was difficult to find the brands of dimmers that were identified by the LED downlight manufacturer as compatible with its product, however. The lamp was tested with a non-compatible dimmer and was found to be difficult to set below 50\%. The lamps either didn't dim enough or turned off and they did not operate in unison. According to the builder, a compatible dimmer was found after PNNL's testing, and it is functioning satisfactorily. LED dimmer compatibility is an area for further manufacturer support and industry action.

Paybacks on the LED downlights ranged from 7.6 years (assuming electricity cost of $11 \mathrm{c} / \mathrm{kWh}$ ) to 13.5 years (at $5 \mathrm{c} / \mathrm{kWh})^{\mathrm{a}}$ based on product costs of $\$ 95$ per LED downlight and 3 hrs per day of usage. Paybacks on the LED undercabinet fixture in a new home ranged from 4.4 years $(11 \mathrm{c} / \mathrm{kWh}$ electricity) to 7.6 years $(5 \mathrm{c} / \mathrm{kWh})$ based on product costs of $\$ 140$ per LED undercabinet fixture at 2 hrs per day of usage. These payback calculations do not take into account labor costs to replace burned out bulbs or fixtures, which are expected to occur much more frequently with halogen and incandescent lamps than with LED products. Paybacks will be shorter if lamps are operated more hours per day, if electricity prices go up, and/or if the initial purchase price goes down for the LED products. These products have been commercially available for less than a year; prices are expected to drop as the technology improves, as component costs decrease, and as sales and competition increase.

\footnotetext{
${ }^{\mathrm{a}}$ The calculations used 5 cents $/ \mathrm{kWh}$ as the average rate for the Springfield area, and 11 cents $/ \mathrm{kWh}$ as the national average.
} 


\section{Contents}

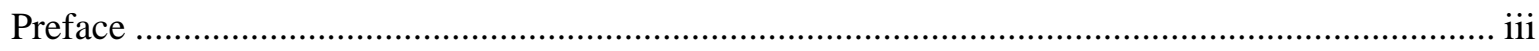

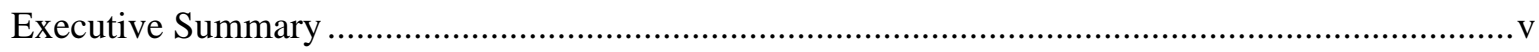

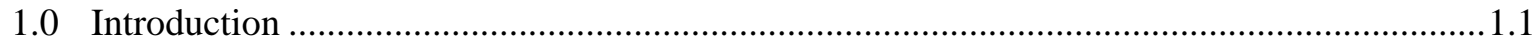

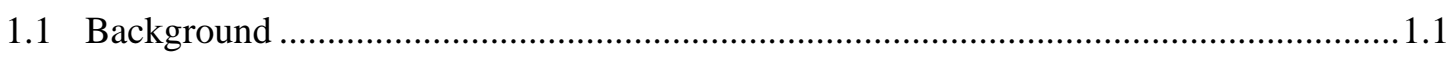

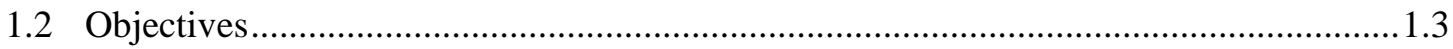

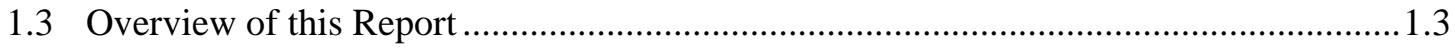

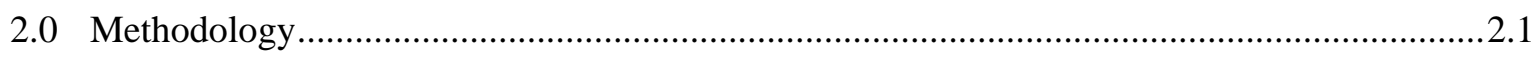

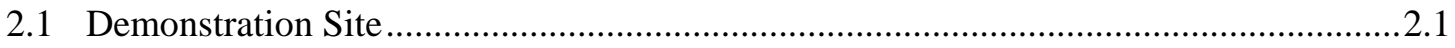

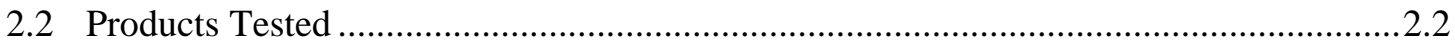

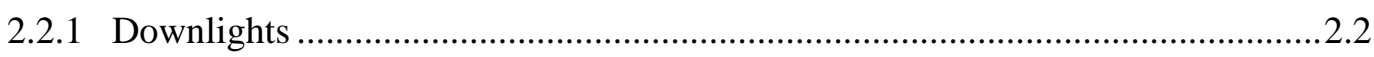

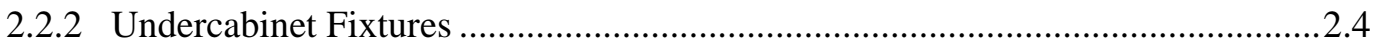

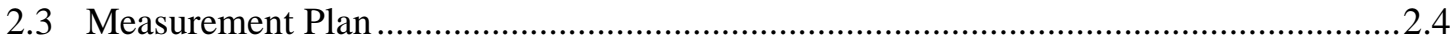

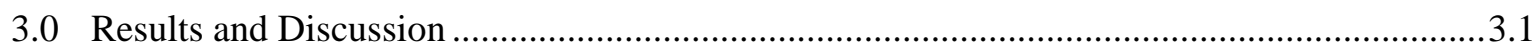

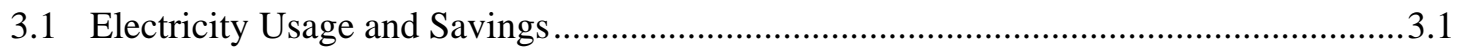

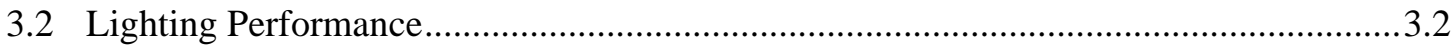

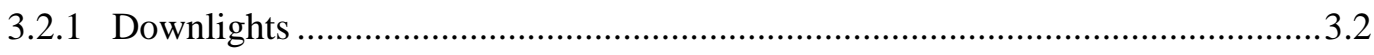

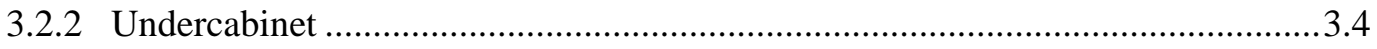

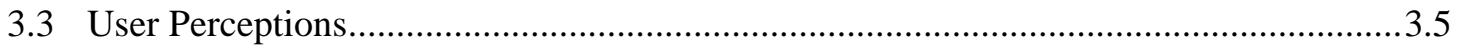

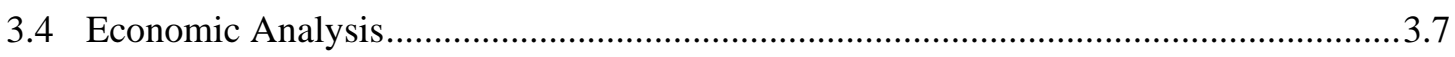

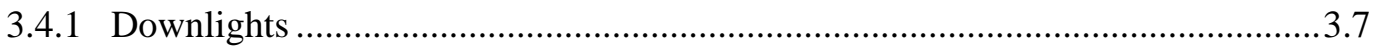

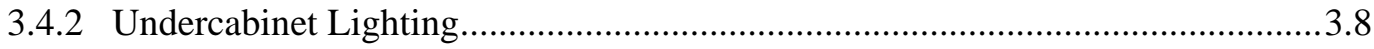

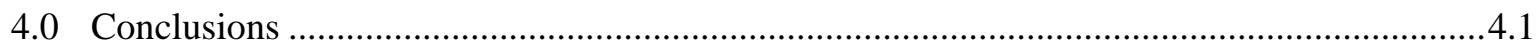

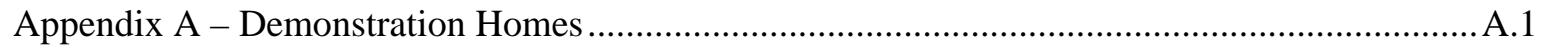

Appendix B - Measurement Equipment \& Conditions …........................................................... B.1

Appendix C - Illuminance-Level Measurement Data ..................................................................

Appendix D - Test Results for Philips eW® Profile Powercore Undercabinet from Independent Laboratory ………….........................................................................

Appendix E - Questionnaire of Builders’ Perception of LED Lighting........................................ E.1

Appendix F - Payback Calculations and Assumptions ..................................................................

Appendix G - Simulations of the LR6 in Homes........................................................................... 


\section{Figures}

Figure 2.1. Lane County HBA and Future B Homes 2008 Tour of Homes Entries ...................... 2.2

Figure 2.2. Cree LED Lighting Solutions’ LR6 LED Module and Installation Instructions ..........2.3

Figure 2.3. Lane County HBA and Future B Homes 2008 Tour of Homes: Kitchens ..................2.3

Figure 2.4. Philips’s eW® Profile Powercore and CSL Counter Attack Undercabinet Fixtures....2.4

Figure 3.1. Installed LR6 Modules at the Lane County HBA Tour Home ....................................3.3

Figure 3.2. Installed LED Undercabinet Fixture..........................................................................

\section{Tables}

Table 2.1. Measurement Details for GATEWAY Demonstration Homes......................................2.5

Table 3.1. Electrical Demand and Energy Savings for Downlight Light Sources............................

Table 3.2. Electrical Demand and Energy Savings for Undercabinet Sources ............................... 3.2

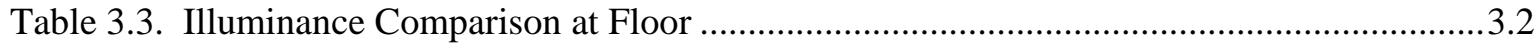

Table 3.4. Illuminance Comparison at Counter Height ..............................................................3.3

Table 3.5. Vertical Illuminance Comparison ...................................................................................

Table 3.6. Illuminance Comparison of Undercabinet Fixtures .................................................... 3.5

Table 3.7. Builders' Responses to Light Qualities........................................................................6

Table 3.8. Builders' Responses to Appearance and Value of the LED Relative to the Conventional Alternative ............................................................................................. 3.7

Table 3.9. Builders Preference for LEDs .................................................................................

Table 3.10. Operating Costs and Payback Estimates for LR6 Modules .........................................

Table 3.11. Operating Costs and Payback Estimates for LED Undercabinet Fixtures: New

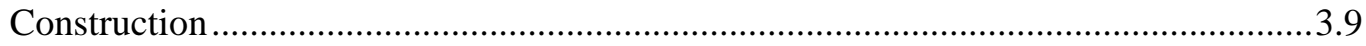

Table 3.12. Operating Costs and Payback Estimates for LED Undercabinet Fixtures: Retrofit

Table 3.13. Operating Costs and Payback Estimates for LED Undercabinet Fixtures:

Retrofit at 4 Hours/Day Use...................................................................................... 3.9

Table 3.14. Operating Costs and Payback Estimates for LED Undercabinet Fixtures: Retrofit at 6 Hours/Day Use. 


\subsection{Introduction}

In August 2008 the Pacific Northwest National Laboratory (PNNL) conducted a light-emitting diode (LED) residential lighting demonstration project for the U.S. Department of Energy (DOE), Office of Building Technologies, as part of DOE's Solid State Lighting (SSL) Technology Demonstration GATEWAY Program. Two lighting technologies, an LED replacement for downlight lamps (bulbs) and an LED undercabinet lighting fixture, were evaluated in the demonstration which was conducted in two homes built for the 2008 Tour of Homes in Eugene, Oregon. The homes were built by the Lane County Home Builders Association (HBA) and Future B Homes. The Energy Trust of Oregon (ETO) also participated in the demonstration project.

The LED downlight product is called the LR6; it was originally developed by LED Lighting Fixtures Corporation (LLF) and is currently sold by Cree LED Lighting Solutions as a replacement for incandescent, compact fluorescent, and halogen lamps in recessed can downlights. It is a unique, integrated module with its own optics, trim, heat sink, and screw (or GU-24) base designed to allow the entire product to be installed in existing recessed downlight fixtures. The second product tested was Philips’ eW® Profile Powercore undercabinet fixture, which was designed to mount under kitchen cabinets to illuminate the countertop and backsplash surfaces.

Quantitative and qualitative measurements of light performance and electrical power usage were taken at each site before and after initially installed halogen and incandescent lamps were replaced with the LED products. Energy savings and simple paybacks were calculated and builders who toured the homes were surveyed for their responses to the LED products.

\subsection{Background}

A number of solid-state lighting-based or LED-based luminaires are currently being introduced into the residential market. Well-designed SSL-based applications have the potential to provide

- greater control of light dispersion

- high-quality light for residential use

- $\quad$ long life

- significant energy savings when compared to incandescent sources

- potentially more control flexibility (dimming) when compared to compact fluorescent sources.

Two residential applications for LEDs that currently can take advantage of these factors are residential downlights and undercabinet lights. 
LEDs are a very directional light source, emitting light in one direction as opposed to most incandescent, halogen, and fluorescent lamps which are omni-directional emitters. ${ }^{a}$ Downlights (or recessed can lights) can take advantage of this inherent directionality of LEDs, minimizing light loss within the fixture. When coupled with recent improvements in LED technology that have significantly improved their efficacy, downlights have emerged as an early, attractive lighting application for LEDs, whose use can make significant energy savings possible. Similarly, LED-based undercabinet lights can also take advantage of the inherently directional nature of LEDs, delivering light to work surfaces as well as the backsplash with minimal losses within the fixtures.

Currently, many new homes use downlights or "cans” for general illumination, primarily with incandescent and halogen lamps, and less frequently with compact fluorescent light (CFL) sources. In fixtures where dimming is desired, most homes will use incandescent or halogen sources. Undercabinet fixtures in residences typically use linear fluorescent or halogen sources. In this application, incandescent and halogen sources are low cost and offer good color rendition and compatibility with the majority of installed controls, relative to the more efficient fluorescent options. LED sources have the potential for even longer life than fluorescent lamps, better light quality, and more energy savings.

LED-based lighting's potential for long life and good light quality has kindled the interest of residential builders around the nation. This is especially true for builders who are seeking to differentiate themselves through the use of greener products and practices. The number of home builders embracing "green" has been increasing in recent years, as home buyers become more aware of energy efficiency and sustainability options.

According to the National Association of Home Builders (NAHB 2007), in 2007, more than half of NAHB's members, accounting for more than $80 \%$ of U.S. homes built, had incorporated green practices into the development, design, and construction of new homes, that were not required by the local building codes. Features such as energy-efficient windows and appliances are now more common, which can help to ease consumer acceptance of newer techniques and technologies, including LEDs.

Residential lighting typically accounts for $15 \%$ to $20 \%$ of U.S. household electricity use, employing a mix of incandescent, fluorescent, and compact fluorescent sources. Recessed downlights (can lights) is one of the fastest growing categories in residential applications. DOE estimates more than 20 million downlights are sold in the U.S. each year, and there are at least 500 million recessed downlights installed

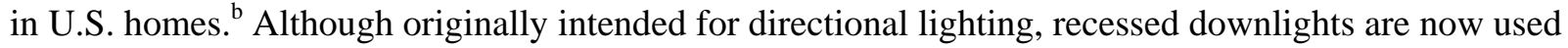
widely for general ambient lighting in kitchens, hallways, bathrooms, and other areas of the home.

Undercabinet lighting is also a popular residential lighting application and is a premium feature in many new and remodelled consumer kitchens. It serves many purposes, ranging from illuminating the surfaces for food preparation tasks to highlighting the counter and backsplash for a more dramatic effect, to night lighting. Many of the newer fixtures use halogen sources to provide both dimming capability and dramatic effects for consumers.

\footnotetext{
${ }^{a}$ LEDs actually emit light in a hemispherical emission pattern, but the light emission is generally referred to as directional.

${ }^{\mathrm{b}}$ LED Application Series: Residential Recessed Downlights. U.S. DOE Energy Efficiency and Renewable Energy, Building Technologies Program, Washington DC, January 2008. Available from http://www.netl.doe.gov/ssl.
} 


\subsection{Objectives}

The objectives of the project were to examine the electrical, lighting, and economic performance of LED products in "real-world" residential downlight and undercabinet lighting applications and to compare the performance of these products with that of incandescent and halogen lamps used in the same applications. One LED downlight product was compared to a comparable halogen lamp and a comparable incandescent lamp. One LED undercabinet fixture was compared to a comparable halogen undercabinet fixture tested at two power levels, low and high. The following metrics were measured or calculated and compared for each product:

- $\quad$ electrical - energy usage and energy savings (both power and estimated annual kWh usage)

- lighting performance - illuminance levels (in footcandles) measured horizontally at counter height and floor height and vertically on walls; illuminance uniformity, correlated color temperature (CCT), color rendering index (CRI)

- dimmability - ability to dim in a manner that satisfies customers

- user perceptions - visibility, brightness, glare, shadows, improvement in home value

- $\quad$ economic performance - simple payback when used as replacement for incandescent or halogen products.

\subsection{Overview of this Report}

Chapter 2 provides a description of the methodology used in this demonstration project, the measurements taken, the analyses conducted, and the results obtained. Chapter 3 is a discussion of results and conclusions. Chapter 4 is references. Appendix A is a description of the two houses used as the demonstration sites, including their dimensions and electrical layouts. Appendix B is a list of the measuring equipment used. Appendix $\mathrm{C}$ is measured data. Appendix D is test results provided by an independent testing laboratory for the undercabinet fixture. Appendix E includes the questionnaire and builders' perceptions about the LED products and results of the survey. Appendix F is the payback calculations. Appendix G is simulation of the LR6 in homes. 
1.4 


\subsection{Methodology}

This chapter includes a description of the site of the demonstration project, the products tested, and measurement methods.

\subsection{Demonstration Site}

The 2008 Eugene Tour of Homes SSL GATEWAY Demonstration Project is a joint project of the U.S. Department of Energy (DOE), Energy Trust of Oregon (ETO), Lane County Homebuilders Association (HBA), and Future B Homes of Eugene, Oregon. ETO's ENERGY STAR Homes Program has been working with Oregon-based builders to help improve the overall energy efficiency of new homes, and they had expressed interest in working with DOE on a residential demonstration of solid-state lighting.

Based on the builders' expressed interest in incorporating LED lighting into their practices, two homes located in the vicinity of Eugene were selected for this assessment with ETO's assistance. These are new homes built by experienced builders for sale to the general public; both were entries in the 2008 Eugene Tour of Homes.

Located in Lane County, Oregon, the Tour of Homes is the Home Builders Association's annual showcase of the top local builders. A 23-year tradition for the county, the 10-day tour takes place at the end of July and is intended to showcase home design ideas, the latest in home innovations, and new building techniques. The tour featured a wide variety of homes open for public viewing, from starter homes to multi-million dollar "dream homes." The 2008 tour included over 20 new homes in the cities of Eugene, Junction City, Veneta, Springfield, Coburg, and Creswell. ${ }^{a}$

The Lane County HBA home is a showcase home constructed each year with contributions from members of the Home Builders Association of Lane County. Proceeds from the sale of the home fund HBA activities and help to promote the local building industry. The 2008 Home was designed to be a "green" showcase, with features such as ENERGY STAR qualification and Earth Advantage ${ }^{\mathrm{TM}}$ certification, roof-mounted photovoltaic panels, tankless water heaters, increased insulation values, carpeting from recycled material, and water-saving landscaping. ${ }^{\text {b }}$ The home built by Future B Homes is also an ENERGY STAR-qualified home. Detailed descriptions of the homes can be found in Appendix A. Both houses are shown in Figure 2.1.

\footnotetext{
${ }^{\mathrm{a}}$ A full listing of homes and descriptions can be found at: http://www.tourofhomes.com/builders choice_home.php

${ }^{\mathrm{b}}$ ENERGY STAR here refers to the NW ENERGY STAR Homes Program administered by the Northwest Energy Efficiency Alliance and the Energy Trust of Oregon (http://www.northwestenergystar.com/). Qualified homes are up to $30 \%$ more efficient than homes built to state code. Earth Advantage is a private, non-profit certification program for homes focusing on energy efficiency, indoor air quality, environmental responsibility, and resource efficiency (http://www.earthadvantagehomes.com).
} 


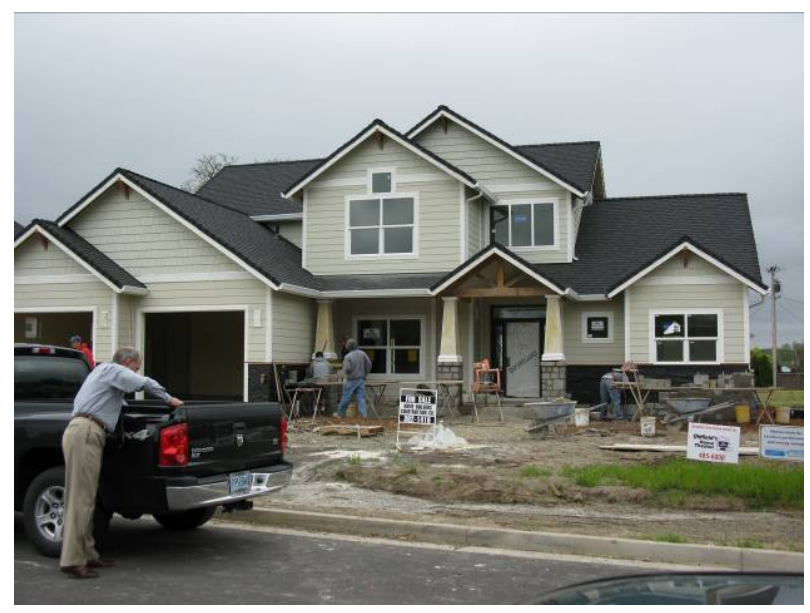

Lane Country HBA

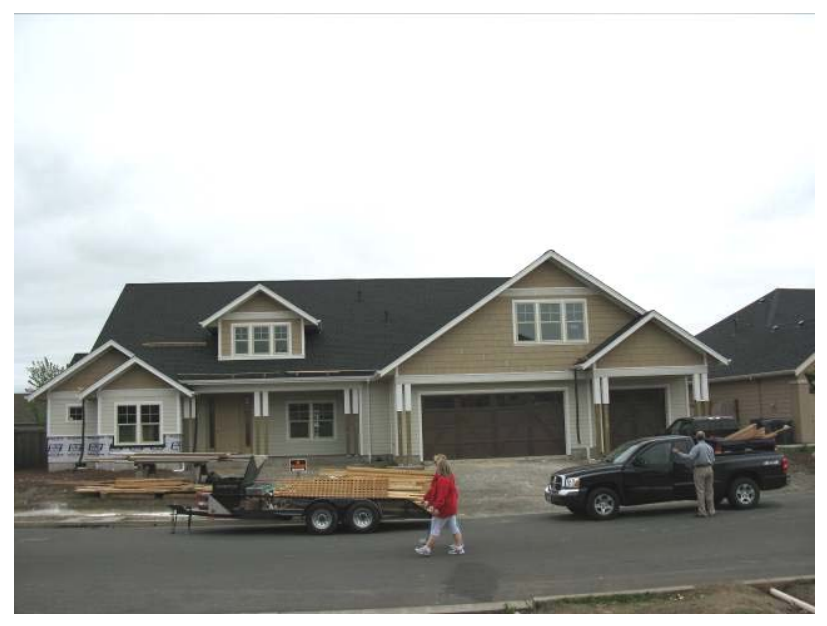

Future B Homes

Figure 2.1. Lane County HBA and Future B Homes 2008 Tour of Homes Entries

\subsection{Products Tested}

The demonstration compared LED downlight replacement modules and undercabinet fixtures to comparable traditional halogen and incandescent products.

\subsubsection{Downlights}

For this project, the two participating builders used Cree LED Lighting Solutions’ LR6 - a unique, integrated LED downlight module with its own optics, trim, heat sink, and screw-in base so it can function as a direct replacement for screw-based reflector lamps (bulbs) in existing recessed can fixtures (Figure 2.2 and 2.3). The LR6 module is designed to be installed in most standard 6-inch insulated contact (IC) or non-IC-rated recessed downlight housings, using either a screw-in medium base or a GU-24 base. 

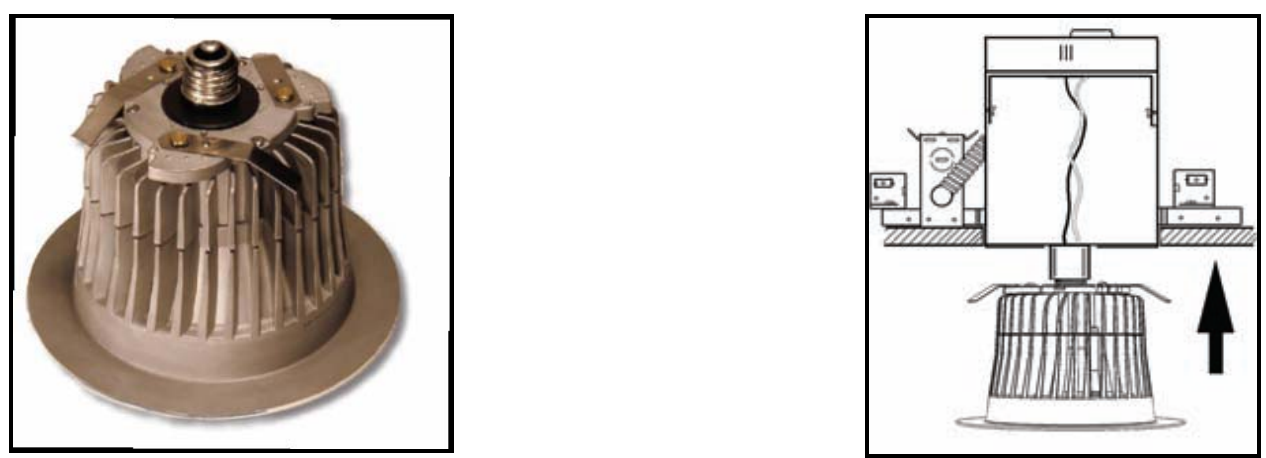

Figure 2.2. Cree LED Lighting Solutions’ LR6 LED Module and Installation Instructions Source: Cree LED Lighting Solutions

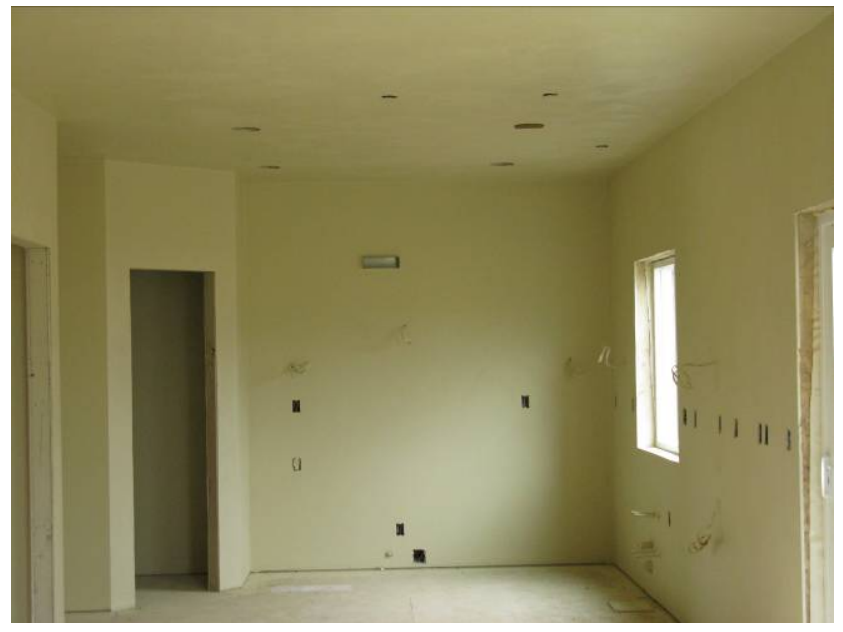

Lane Country HBA

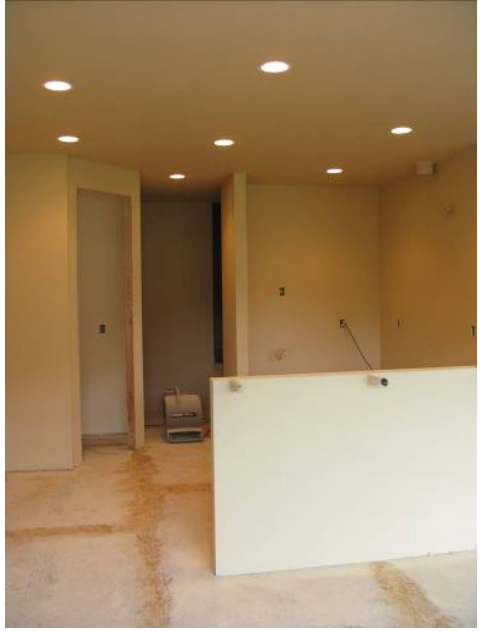

Future B Homes

Figure 2.3. Lane County HBA and Future B Homes 2008 Tour of Homes:

Kitchens (under construction)

For the Future B Homes’s 2008 tour entry, the LR6 units were installed in Lightolier-brand downlight housings, and for the Lane County HBA's 2008 tour entry, the LR6 units were installed in Halo-brand downlight housings. Future B Homes installed a total of 12 Cree LR6 modules in their kitchen and dining areas. Lane County HBA installed 17 LR6 units throughout their model home, in the kitchen, dining room, living room, hallways, and bathrooms. Both homes’ dimensions are shown in Appendix A.

To allow for comparisons, the downlight fixtures in the Future B Homes' kitchen and dining areas were initially installed with 75W PAR38 halogen lamps, while Lane County HBA's kitchen and living areas used 65W BR30 incandescent lamps. Downlight housings and light sources were the choices of the local electricians and builders. 


\subsubsection{Undercabinet Fixtures}

Lane County HBA also installed four Philips' eW Profile Powercore LED undercabinet fixtures in the kitchen of their home. Philips' eW Profile Powercore is a low-profile linear LED fixture intended for undercabinet lighting, task lighting, and display case lighting (see Figure 2.4). Powered by line voltage (with a built-in power supply), it can support a run of up to 50 linear feet of fixtures on a single circuit. The fixture can be installed to illuminate work surfaces and displays in both commercial and residential settings. The fixture is available in three standard lengths: 9.25, 19.25, and 39.25 inches. The 19.25-in. units were used in the Lane County HBA home. The eW Profile Powercore LED units replaced four 24in. three-light "Counter Attack" halogen (xenon-based) undercabinet fixtures made by CSL (Creative System Lighting, Inc.) that had been initially installed. The CSL halogen fixtures were the light sources chosen by the local electricians and builders. The CSL halogen undercabinet lights had the capability of operating at two different light levels - a high setting drawing 105 Watts per fixture and a low setting drawing about 60 Watts. Illuminance measurements were taken at both settings.

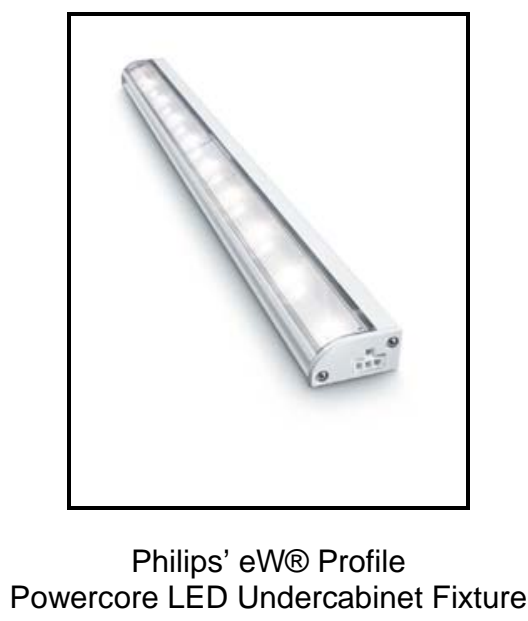

Figure 2.4. Philips’s eW® Profile Powercore and CSL Counter Attack Undercabinet Fixtures Source: Philips and CSL

\subsection{Measurement Plan}

Similar measurement plans were developed for each home. PNNL did a pre-test visit to the sites to assess any potential issues. One potential issued was identified regarding testing of the downlights: because both homes were still under construction, the countertops were not in and tables were not set up for the measurements, so it was difficult to take measurements at the actual task plane height. Therefore, most of the measurements were taken at floor level, although a limited set of measurements were taken at approximate counter height at both homes. All of the measurements for the downlights were taken in one visit. Measurements were taken with the halogen and incandescent lamps installed in the downlights then those lamps were replaced with the LR6 LED modules and another set of measurements were taken. 
Illuminance measurements for the Future B Homes were taken over an area containing 12 luminaires, with four luminaires located in the dining area and eight in the kitchen area. The spacing for the kitchen luminaires and dining luminaires was approximately four-feet on center; both areas were at a nine-feet ceiling height.

Illuminance measurements for the HBA home were taken over two areas containing eight luminaires, with four luminaires located in the dining area and four luminaires located in the living area. The spacing for the kitchen luminaires was approximately $4 \mathrm{ft}$ on center at a 9-ft ceiling height and the spacing for the living area was approximately $8 \mathrm{ft}$ on center at a $17-\mathrm{ft}$ ceiling height. Selected vertical illuminance measurements were also taken on the walls in the kitchen and living area of the HBA home. Table 2.1 contains details of the measurement areas.

Table 2.1. Measurement Details for GATEWAY Demonstration Homes

\begin{tabular}{|r|c|c|c|c|}
\hline Location & $\begin{array}{c}\text { Measurement } \\
\text { Area }\end{array}$ & $\begin{array}{c}\text { Approximate } \\
\text { Grid Area }\end{array}$ & $\begin{array}{c}\text { Approximate Grid } \\
\text { Spacing }\end{array}$ & $\begin{array}{c}\text { Measurement } \\
\text { Height }\end{array}$ \\
\hline $\begin{array}{r}\text { Future B } \\
\text { Homes }\end{array}$ & Kitchen & $9 \mathrm{ft} \times 9 \mathrm{ft}$ & $3 \mathrm{ft}$ & Floor \\
\cline { 2 - 5 } & Dining & $10 \mathrm{ft} \times 10 \mathrm{ft}$ & $3 \mathrm{ft}$ & Floor \\
\hline Lane County \\
\cline { 2 - 5 } HBA
\end{tabular}

For the Color Kinetics eW fixtures, the installation and measurements took place on separate evenings, because the halogen undercabinet fixtures were not yet installed at the time of the LR6 installation (the halogen fixtures themselves had not yet been installed). Illuminance measurements for the undercabinet fixtures were taken at the counter surface level, over a counter area measuring approximately 30 in. by 50 in. at a 36 in. counter height.

Appendix B contains a listing of the equipment used for the measurement process.

CRI and CCT data for the two LED fixture types investigated were obtained from an independent lighting test laboratory contracted by PNNL to test the fixtures. CRI and CCT data for the halogen and incandescent lamps were assumed based on manufacturers’ specifications.

Consumer perceptions of the incandescent/halogen and LED lights were obtained through a questionnaire given to builders who visited the homes during the 2008 Eugene Tour of Homes (a summary of the questionnaire and results are included in Appendix F). 


\subsection{Results and Discussion}

\subsection{Electricity Usage and Savings}

In the HBA home, each LR6 LED module drew roughly 82\% (53 Watts) less than the 65W BR30 incandescent lamp it replaced. In the Future B Homes house, each LR6 LED module drew about 84\% (63 Watts) less than the 75W PAR38 halogen lamp it replaced. Based on California's Database for Energy Efficiency Resource (DEER) and other available usage data, kitchen and dining room downlights typically operate on average about 3 hours per day. ${ }^{a}$ At this level of daily operation, annual electrical savings are estimated to range from about $58 \mathrm{kWh}$ to $69 \mathrm{kWh}$ per downlight replaced with an LR6 module. Table 3.1 below provides a comparison of the energy consumption for each of the light sources.

Table 3.1. Electrical Demand and Energy Savings for Downlight Light Sources

\begin{tabular}{|l|r|r|r|r|}
\cline { 2 - 5 } \multicolumn{1}{c|}{} & \multicolumn{1}{c|}{$\begin{array}{l}\text { Lamp } \\
\text { Watts }\end{array}$} & $\begin{array}{c}\text { Hrs/day } \\
\text { Use }\end{array}$ & $\begin{array}{c}\text { Annual } \\
\text { kWh }\end{array}$ & $\begin{array}{c}\text { Energy } \\
\text { Savings } \\
\text { (\%) }\end{array}$ \\
\hline LR6 Module & 12 & 3 & 13.1 & \\
\hline BR30 & 65 & 3 & 71.2 & $82 \%$ \\
\hline PAR38 & 75 & 3 & 82.1 & $84 \%$ \\
\hline
\end{tabular}

The Philips LED undercabinet fixture use 10 Watts per fixture compared to the halogen undercabinet fixture, which draws 105 Watts at the high setting and 60 Watts at the low setting. Thus the LED undercabinet fixture uses $91 \%$ less energy than the halogen fixture at the high light setting and $83 \%$ less energy than the halogen fixture at the low light setting (see Table 3.2 below).

It is important to note that these are not direct comparison, because the LED undercabinet fixture did not provide the same amount of light as the halogen fixture (footcandle [fc] measurements are $35.8 \mathrm{fc}$ for the LED fixture versus $13.4 \mathrm{fc}$ for the low halogen and $53.4 \mathrm{fc}$ for the high halogen; see lighting performance below.) At about 2 hours of use per day, which is the estimated minimum for these types of fixtures, each LED undercabinet fixture has the potential to save $69.4 \mathrm{kWh} / \mathrm{yr}$ compared to the halogen fixture at high setting and $36.5 \mathrm{kWh} / \mathrm{yr}$ compared to the halogen fixture at low setting. ${ }^{\mathrm{b}}$

\footnotetext{
${ }^{\mathrm{a}}$ http://www.energy.ca.gov/deer/ Note that the average value is rounded to 3 hours.

b Lighting Efficiency Technology Report, Volume I: California Baseline. California Energy Commission Consultant Report. September 1999. State of California.
} 
Table 3.2. Electrical Demand and Energy Savings for Undercabinet Sources

\begin{tabular}{|l|r|r|r|r|}
\cline { 2 - 5 } \multicolumn{1}{c|}{} & $\begin{array}{c}\text { Lamp } \\
\text { Watts }\end{array}$ & $\begin{array}{c}\text { Hrs/day } \\
\text { Use }\end{array}$ & $\begin{array}{c}\text { Annual } \\
\text { kWh }\end{array}$ & $\begin{array}{c}\text { Energy } \\
\text { Savings } \\
\mathbf{( \% )}\end{array}$ \\
\hline eW Powercore LEDs & 10 & 2 & 7.3 & \\
\hline Halogen Low Level & 60 & 2 & 43.8 & $83.3 \%$ \\
\hline Halogen High Level & 105 & 2 & 76.7 & $90.5 \%$ \\
\hline
\end{tabular}

\subsection{Lighting Performance}

\subsubsection{Downlights}

The LED LR6 modules improved light levels across all surveyed areas compared to both the 65W BR30 and 75W PAR38 lamps. The LED modules consistently provided higher maximum and minimum light levels, and therefore higher average light levels in both homes. In addition, the LEDs also provided slightly better light uniformity (lower uniformity ratios) than the halogen lamps - although the differences are too small to be perceivable. Table 3.3 below provides the measured and calculated values for the two homes. A complete listing of light performance data is provided in Appendix C.

Table 3.3. Illuminance Comparison at Floor

\begin{tabular}{|c|c|c|c|c|}
\hline \multirow{2}{*}{ Future B Homes } & \multicolumn{2}{|c|}{ Kitchen/Dining (9 ft height) } & & \\
\hline & \begin{tabular}{|l|} 
PAR38 \\
\end{tabular} & LEDs & & \\
\hline Max light level at floor (fc) & 12.4 & 14.2 & & \\
\hline Min light level at floor (fc) & 7.0 & 8.9 & & \\
\hline Average light level $\left(f_{c}\right)$ & 9.6 & 11.6 & & \\
\hline Max/Min Ratio & 1.8 & 1.6 & & \\
\hline \multirow{2}{*}{ Lane County HBA } & \multicolumn{2}{|c|}{ Kitchen (9 ft height) } & \multicolumn{2}{|c|}{ Living (17 ft height) } \\
\hline & BR30 & LEDs & BR30 & LEDs \\
\hline Max light level at floor (fc) & 10.1 & 12.0 & 3.4 & 4.4 \\
\hline Min light level at floor (fc) & 8.6 & 10.1 & 2.6 & 3.7 \\
\hline Average light level (fc) & 9.2 & 10.7 & 3.1 & 4.1 \\
\hline Max/Min Ratio & 1.2 & 1.2 & 1.3 & 1.2 \\
\hline
\end{tabular}

The LED LR6 modules also provided more light at the counter height (36 inches) or task plane level, compared to both the 65W BR30 and 75W PAR38 lamps. The LED modules consistently provided higher maximum and minimum light levels on the counter in both homes. Figure 3.1. shows the installed LR6 units in the kitchen of the Lane County HBA home. 


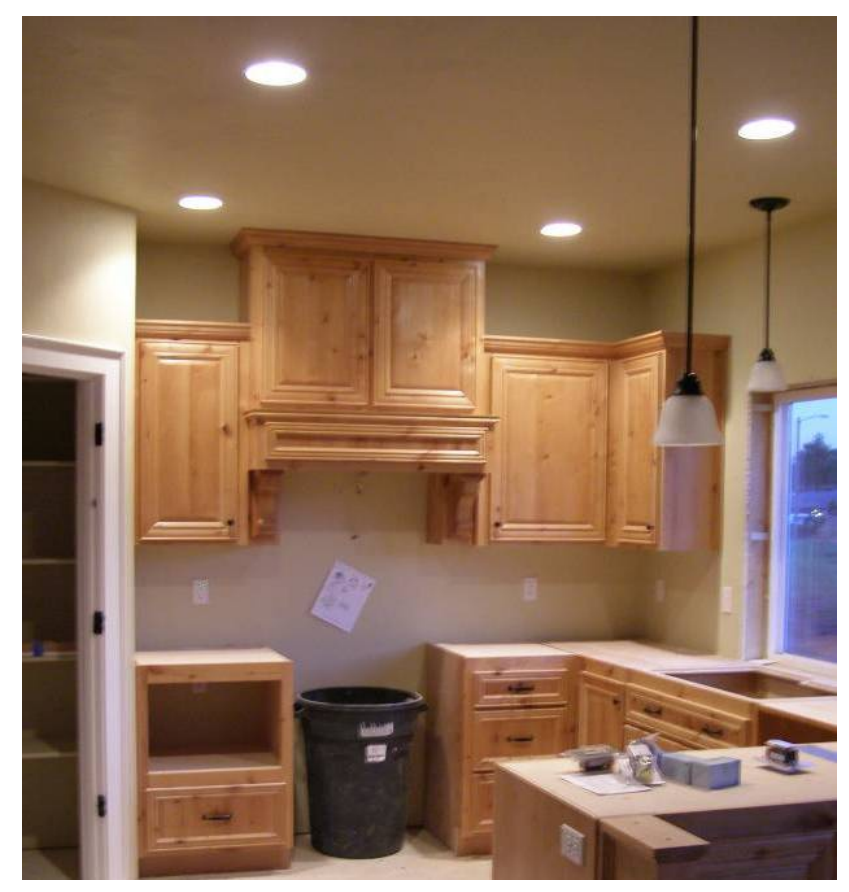

Figure 3.1. Installed LR6 Modules at the Lane County HBA Tour Home

The LEDs provided slightly less light uniformity at the task plane level (higher uniformity ratios) than the halogen lights in the Future B Homes house and greater uniformity than the incandescent lights in the Lane County HBA home. Table 3.4 below provides the measured and calculated values for the two homes.

Table 3.4. Illuminance Comparison at Counter Height

\begin{tabular}{|l|r|r|r|r|}
\cline { 2 - 5 } \multicolumn{1}{c|}{} & \multicolumn{2}{c|}{ Future B Homes } & \multicolumn{2}{c|}{ Lane County HBA } \\
\cline { 2 - 5 } \multicolumn{1}{c|}{} & PAR38 & \multicolumn{1}{c|}{ LEDs } & \multicolumn{1}{c|}{ BR30 } & \multicolumn{1}{c|}{ LEDs } \\
\hline Max light level at counter $(\mathrm{fc})$ & 15.5 & 19.1 & 13.0 & 15.1 \\
\hline Min light level at counter $(\mathrm{fc})$ & 7.3 & 8.6 & 5.0 & 8.3 \\
\hline Average light level $(\mathrm{fc})$ & 12.0 & 14.3 & 9.7 & 12.5 \\
\hline Max/Min & 2.1 & 2.2 & 2.6 & 1.8 \\
\hline
\end{tabular}

Performance was also measured on vertical surfaces in the Lane County HBA home, and the LED modules were found to provide more vertical illuminance (more light on the walls or better lateral dispersion) than the BR30 incandescent lamps installed at the home. Table 3.5 provides the vertical illuminance measured on the east living area wall and on the south kitchen wall at the Lane County HBA home. 
Table 3.5. Vertical Illuminance Comparison

\begin{tabular}{|l|r|r|r|r|}
\hline \multirow{2}{*}{ Vertical Distance } & \multicolumn{3}{|c|}{ Living Area East Wall } & \multicolumn{2}{c|}{ Kitchen Area South Wall } \\
\cline { 2 - 5 } \multicolumn{1}{|c|}{ BR30 } & \multicolumn{1}{c|}{ LEDs } & \multicolumn{1}{c|}{ BR30 } & \multicolumn{1}{c|}{ LEDs } \\
\hline Light level at 2 ft (fc) & 1.7 & 2.6 & 2.5 & 4.6 \\
\hline Light level at 4 ft (fc) & 1.8 & 2.7 & 5.7 & 9.3 \\
\hline Light level at 6ft (fc) & 1.9 & 2.9 & 6.9 & 12.5 \\
\hline Light level at 8ft (fc) & 2.0 & 3.4 & NA & NA \\
\hline
\end{tabular}

The color rendering index of the LR6 was tested by an independent lighting test lab and found to be 93, which also compares favorably with the incandescent and halogen CRI score of $100 .^{\text {a }}$

Aside from its light output and long life, another important aspect of LED lighting that makes it attractive to builders is its dimming capabilities. Builders were provided with Cree LED Lighting Solutions' list of LR6-compatible dimmers in preparation for the installation. ${ }^{\mathrm{b}}$ Both builders were unable to obtain compatible dimmers at the time of installation. Future B Homes had a Lutron-brand dimmer installed as a place holder at the time of installation, while HBA used a simple on-off switch for their kitchen light control.

With the Lutron dimmer, which is not listed as a LR6 compatible dimmer by Cree LED Lighting Solutions, the LR6 units were able to reach full output, but their dimming performance was uneven and quite truncated. At the $50 \%$ setting, the light levels of the LED units were not at the $50 \%$ mark. ${ }^{\mathrm{c}}$ In fact, they were much higher. However, when the dimmer was moved to levels lower than the $50 \%$ mark, the LR6 units had difficulty reaching levels below 50\% output and quickly turned off. The LR6 units also flickered and turned off individually (in no particular sequence) rather than in unison when the dimmer was set to the lowest level. Future B Homes has ordered and installed a compatible dimmer from the dimmer families recommended as "compatible" by the manufacturer after PNNL's measurement visit and reported that it is functioning satisfactorily.

\subsubsection{Undercabinet}

Two types of measurements were taken for the undercabinet lighting - a horizontal measurement of lighting levels on the counter top surface and a vertical measurement on the backsplash. It was possible to make a direct comparison of the lighting performance of the LED and halogen undercabinet fixtures on the horizontal surface but it was not possible to directly compare the vertical measurements on the backsplash. This was because the LED fixtures were not installed in the same location as the halogen fixtures they replaced. The halogen fixtures had been mounted under the cabinets along the back wall. A junction box installed after the halogen fixtures were removed blocked part of the back wall so the LED fixtures had to be mounted along the front edge of the cabinets (Figure 3.2). Furthermore, the halogen fixtures had two levels of light output, whereas the LED fixtures did not.

\footnotetext{
${ }^{\text {a }}$ CALiPER Report \#07-31

${ }^{\mathrm{b}}$ Available from http://creelighting.com/downloads/Dimmer_Compatibility_Rev011608.pdf.

c The PAR38 at the Future B Homes' location were dimmed to 50\% setting with the installed PAR38, and this setting was marked prior to removal and installation of the LR6s.
} 


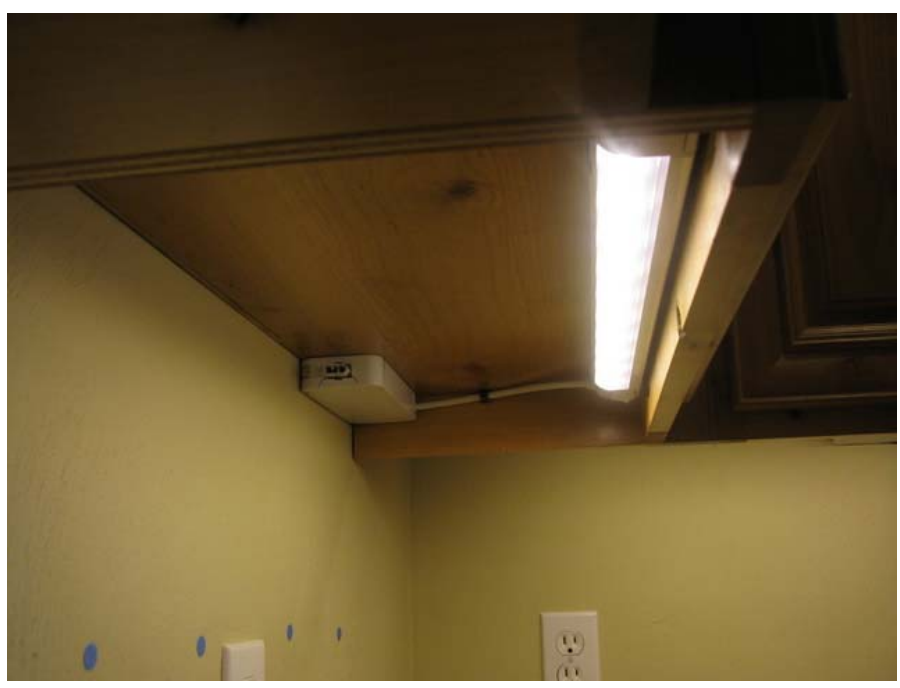

Figure 3.2. Installed LED Undercabinet Fixture

The illuminance provided by the LED fixtures on the countertop fell in between the high and low levels of the halogen. While the LEDs could not match the higher average level provided by the halogen at the high setting, the average illuminance level provided by the LED unit exceeded IESNA recommended level (30 foot-candles) for work surfaces. Further, the LED fixtures were able to provide a more even illumination on the countertops, as evidenced by the lower uniformity ratio (7 vs. 10.8) compared to the halogen fixtures. The LED fixtures also provided a minimum light level quite close to the minimum level obtained at the high setting of the halogen fixture (Table 3.6).

Table 3.6. Illuminance Comparison of Undercabinet Fixtures

\begin{tabular}{|l|r|r|r|}
\cline { 2 - 4 } \multicolumn{1}{c|}{} & Halogen Lo & Halogen Hi & \multicolumn{1}{c|}{ LEDs } \\
\hline Max light level at counter (fc) & 29.3 & 115.1 & 56.5 \\
\hline Min light level at counter (fc) & 2.7 & 10.7 & 8.1 \\
\hline Average light level (fc) & 13.4 & 53.4 & 35.8 \\
\hline Max/Min & 10.9 & 10.8 & 7.0 \\
\hline
\end{tabular}

The CCT performance of the LED undercabinet fixtures was measured at an independent testing laboratory contracted by PNNL. They reported it to be $2880 \mathrm{~K}$, which compares favorably with the halogen CCT of $2700 \mathrm{~K}$ (or higher). The color rendering index of the eW Profile Powercore tested was reported to be 71 . The independent testing data is available in Appendix D.

\subsection{User Perceptions}

Both Lane County HBA and Future B Homes were impressed with the performance of the LR6 LED downlight's performance. The two builders were impressed with the light output of the LED modules when compared to incandescent lamps. Although the measurable differences in the light levels were slight, both builders commented that the LED modules were brighter. They also cited instant starting and the overall positive effects of the new lights on the appearance of the illuminated areas as reasons for their high satisfaction. 
The Lane County HBA representative also had a positive reaction to the Philips undercabinet luminaire, and especially noted the ability of the LED-based source to more closely approximate the "sparkle" factor of the halogen sources when compared to fluorescent sources. In fact, this "sparkle" factor has been cited by a number of builders as an important consideration in their selection of undercabinet lighting, especially if natural materials such as stone or other counter and backsplash choices that require highlighting are chosen.

A subsequent inquiry with local builders indicated a more cautious but still positive reception of the new LED technology. About two dozen builders were given a questionnaire regarding the LED light sources, and 12 responded, although only about half of the respondents saw the installed LED modules at the Future B Homes' model home. All 12 were able to view the installed fixtures at the Lane County HBA home and were able to comment on them. The responses indicated an overall favorable impression of the LED light sources. Table 3.7 to Table 3.9 below contain a summary of the responses.

Table 3.7. Builders’ Responses to Light Qualities

\begin{tabular}{|r|c|c|c|}
\hline \multicolumn{4}{|c|}{ Brightness, Shadow and Glare } \\
\hline Light level with LEDs & More & Same & Less \\
\hline Future B Homes kitchen \& dining & $67 \%$ & $33 \%$ & $0 \%$ \\
\hline Lane County HBA kitchen \& living & $58 \%$ & $25 \%$ & $17 \%$ \\
\hline Lane County HBA undercabinet & $17 \%$ & $33 \%$ & $50 \%$ \\
\hline Shadow amount with LEDs & & & \\
\hline Future B Homes kitchen \& dining & $33 \%$ & $33 \%$ & $33 \%$ \\
\hline Lane County HBA kitchen \& living & $33 \%$ & $42 \%$ & $25 \%$ \\
\hline Lane County HBA undercabinet & $17 \%$ & $50 \%$ & $33 \%$ \\
\hline Glare amount with LEDs & & & \\
\hline Future B Homes kitchen \& dining & $33 \%$ & $33 \%$ & $33 \%$ \\
\hline Lane County HBA kitchen \& living & $17 \%$ & $25 \%$ & $58 \%$ \\
\hline Lane County HBA undercabinet & $17 \%$ & $17 \%$ & $67 \%$ \\
\hline
\end{tabular}

About half or more of the respondents thought that the LR6 units provided somewhat more light than the incandescent sources, as indicated in Table 3.7 above. A significant number of respondents also thought that the LR6 units were less "glary" and created less shadow than their incandescent and halogen counterparts.

A large number of builders also thought that the new light sources had a more positive impact on overall visibility and helped to improve the appearance of the illuminated area (Table 3.8). Specific to the Philips undercabinet luminaires, a number of builders commented favorably on the fact that the LED fixtures provided a lower light level (the halogen was too bright in the high setting) and a more uniform light than the halogen counterparts. Builders also commented on the fact that LEDs do not get as hot, and that they like the "sparkle" factor. More significantly, the majority thought that the new lights (both undercabinets and downlights) added to the overall value of the houses. 
Table 3.8. Builders' Responses to Appearance and Value of the LED Relative to the Conventional Alternative

\begin{tabular}{|r|c|c|c|}
\hline Overall visibility & More & Same & Less \\
\hline Future B Homes kitchen \& dining & $67 \%$ & $33 \%$ & $0 \%$ \\
\hline Lane County HBA kitchen \& living & $50 \%$ & $33 \%$ & $17 \%$ \\
\hline Lane County HBA undercabinet & $67 \%$ & $33 \%$ & $0 \%$ \\
\hline Improvement in home appearance & & & \\
\hline Future B Homes kitchen \& dining & $67 \%$ & $33 \%$ & $0 \%$ \\
\hline Lane County HBA kitchen \& living & $58 \%$ & $33 \%$ & $0 \%$ \\
\hline Lane County HBA undercabinet & $75 \%$ & $25 \%$ & $0 \%$ \\
\hline Improvement in home value & & & \\
\hline Future B Homes kitchen \& dining & $83 \%$ & $17 \%$ & $0 \%$ \\
\hline Lane County HBA kitchen \& living & $83 \%$ & $17 \%$ & $0 \%$ \\
\hline Lane County HBA undercabinet & $75 \%$ & $25 \%$ & $0 \%$ \\
\hline
\end{tabular}

Builders were asked, do you prefer the old light or the new LED lights? The majority preferred the new lights as shown in Table 3.9.

Table 3.9. Builders Preference for LEDs (New)

\begin{tabular}{|r|c|c|}
\hline Fixture preference & New & Old \\
\hline Future B Homes kitchen \& dining & $67 \%$ & $33 \%$ \\
\hline Lane County HBA kitchen \& living & $67 \%$ & $33 \%$ \\
\hline Lane County HBA undercabinet & $67 \%$ & $33 \%$ \\
\hline
\end{tabular}

Finally, PNNL spoke with the builders during the Tour of Homes show. A number of the builders indicated their willingness to use the new light sources in their new or upcoming projects. One builder indicated that he has already sourced a number of LR6 units for his new projects, while a number of others committed to monitoring prices so that they can take advantage of the new light sources when it makes sense for them economically. Most also indicated their willingness to specify LED undercabinet products. A representative selection of their comments are provided in Appendix E. While the surveyed population probably contains a higher percentage of progressive builders, these responses indicated that the installed products are performing to their expectations.

\subsection{Economic Analysis}

Economic performance was evaluated by calculating the simple paybacks for the LED sources versus the incandescent sources. To calculate this, current energy and materials costs were used to calculate annual maintenance cost and energy cost.

\subsubsection{Downlights}

The retail price of the LR6 product varied at the time of the study from a low of \$69.99 to a high of $\$ 149.99$ or more. The price used in PNNL's calculations is the actual "builders price” paid for multiple units from a local distributor in Portland, Oregon - \$95 per unit. 
To estimate energy cost, two residential electricity rates were used: a rate local to Eugene, Oregon (5 cents per $\mathrm{kWh}$ ) and an average national rate (11 cents per $\mathrm{kWh}$ ). Under these rates, the LR6 LED replacement modules yielded annual energy savings of $\$ 2.90$ to $\$ 8.71$ per unit when compared to $65 \mathrm{~W}$ incandescent BR30 lamps, and \$3.45 to \$10.35 per unit when compared to 75W halogen PAR38 lamps, based on 3 hours of use per day. ${ }^{\text {a }}$

Because of the manufacturer's long claimed life, the LED modules were assumed to not have to be replaced over the life of the fixture (i.e., they have zero lamp replacement cost over the course of their useful life. ${ }^{b}$ ) In comparison the halogen and incandescent lamps are rated by the manufacturers to last 1000 hours for an estimated life of approximately 1 year, if operated 3 hours per day, thus their replacement cost was assumed to be $\$ 3.50$ per year for the lamp itself. Labor costs to replace the lamps (i.e., the cost of renting a ladder or hiring someone to come in and replace the lamps - a possibility with high ceilings such as the 17 foot living area at the Lane County HBA home) was not included in the calculations. The simple payback periods for the LED modules (based on their current cost and assumed operational costs of the other sources) is between 7.6 and 13.5 years when they are used in place of incandescent or halogen lamps. Table 3.10 below contains the cost calculations, assumptions, and payback results.

Table 3.10. Operating Costs and Payback Estimates for LR6 Modules

\begin{tabular}{|c|c|c|c|c|c|c|c|c|c|c|c|}
\hline \multirow[b]{2}{*}{ LED Module } & \multicolumn{2}{|c|}{$\begin{array}{c}\text { Energy } \\
\text { Cost/Year } \\
@ 5 c / k W h\end{array}$} & \multicolumn{2}{|c|}{$\begin{array}{c}\text { Energy } \\
\text { Cost/Year } \\
@ 11 \mathrm{c} / \mathrm{kWh}\end{array}$} & \multirow[t]{2}{*}{$\begin{array}{l}\text { Replacement } \\
\text { lamp cost/year }\end{array}$} & \multicolumn{2}{|c|}{$\begin{array}{c}\text { Annual } \\
\text { Operating } \\
\text { Costs @ 5c } \\
\text { (elec + lamp) }\end{array}$} & \multicolumn{2}{|c|}{$\begin{array}{c}\text { Annual } \\
\text { Operating } \\
\text { Costs @ 11c } \\
\text { (elec. + lamp) }\end{array}$} & \multirow[t]{2}{*}{$\begin{array}{c}\text { LEDs } \\
\text { Payback @ } \\
5 \mathrm{c} / \mathrm{kWh}\end{array}$} & \multirow[t]{2}{*}{$\begin{array}{c}\text { LEDs } \\
\text { Payback @ } \\
\text { 11c/kWh }\end{array}$} \\
\hline & $\$$ & 0.66 & $\$$ & 1.45 & & $\$$ & 0.66 & $\$$ & 1.45 & & \\
\hline BR30 & $\$$ & 3.56 & $\$$ & 7.83 & 3.50 & $\$$ & 7.06 & $\$$ & 11.33 & 13.5 & 8.4 \\
\hline PAR38 & $\$$ & 4.11 & $\$$ & 9.03 & 3.50 & $\$$ & 7.61 & $\$$ & 12.53 & 12.5 & 7.6 \\
\hline
\end{tabular}

Notes: See Appendix F for assumptions. The LR6 cost for this project is $\$ 95 /$ unit.

\subsubsection{Undercabinet Lighting}

Two payback scenarios were run for the undercabinet lighting: a new construction scenario and a retrofit scenario (Table 3.11 and Table 3.12). In both scenarios, the LED undercabinet fixture was compared to the halogen undercabinet fixture at both its low and the high power operation levels because those levels used different amounts of energy and thus had different annual operating costs.

In the case of new construction, the house will have undercabinet kitchen lighting so the fixture cost used in the calculation is either the cost of the halogen fixture (\$80) or the difference in cost between the LED fixture and the halogen fixture $(\$ 140$ LED fixture - $\$ 80$ halogen fixture $=\$ 60$ per unit cost for the LED fixtures). Again the LED fixtures were assumed to have zero lamp replacement cost due to their long useful life. Therefore, in the new construction scenario, the simple payback period for the LED fixtures (based on their current cost and the assumed operational costs of the other sources) is between 4.4 and 7.6 years when the LED is used instead of an incandescent or halogen lamp.

\footnotetext{
${ }^{\text {a }}$ See Appendix F: Payback Calculations.

${ }^{\mathrm{b}}$ Cree LED Lighting Solutions specifies 70\% lumen depreciation at 50,000 hours. At 3 hours per day, this works out to be 45.6 years. A more realistic assumption is that the modules will remain until the kitchen is remodeled, at about 7 years on average.
} 
Table 3.11. Operating Costs and Payback Estimates for LED Undercabinet Fixtures: New Construction

\begin{tabular}{|c|c|c|c|c|c|c|c|c|c|c|c|}
\hline \multirow[b]{2}{*}{ eW Powercore LEDs } & \multicolumn{2}{|c|}{$\begin{array}{c}\text { Energy } \\
\text { Cost/Year } \\
@ 5 c / k W h\end{array}$} & \multicolumn{2}{|c|}{$\begin{array}{c}\text { Energy } \\
\text { Cost/Year } \\
@ 11 \mathrm{c} / \mathrm{kWh}\end{array}$} & \multirow[t]{2}{*}{$\begin{array}{l}\text { Replacement } \\
\text { lamp } \\
\text { costs/year }\end{array}$} & \multicolumn{2}{|c|}{$\begin{array}{c}\text { Annual } \\
\text { Operating } \\
\text { Costs @ 5c } \\
\text { (elec + lamp) }\end{array}$} & \multicolumn{2}{|c|}{$\begin{array}{c}\text { Annual } \\
\text { Operating } \\
\text { Costs @ 11c } \\
\text { (elec. + lamp) }\end{array}$} & \multirow[t]{2}{*}{$\begin{array}{c}\text { LEDs } \\
\text { Payback @ } \\
\text { 5c/kWh }\end{array}$} & \multirow[t]{2}{*}{$\begin{array}{c}\text { LEDs } \\
\text { Payback @ } \\
\text { 11c/kWh }\end{array}$} \\
\hline & $\$$ & 0.37 & $\$$ & 0.80 & & $\$$ & 0.37 & $\$$ & 0.80 & & \\
\hline CSL Xenon Low Level & $\$$ & 2.19 & $\$$ & 4.82 & 6.12 & $\$$ & 8.31 & $\$$ & 10.94 & 7.6 & 5.9 \\
\hline CSL Xenon High Level & $\$$ & 3.83 & $\$$ & 8.43 & 6.12 & $\$$ & 9.95 & $\$$ & 14.55 & 6.3 & 4.4 \\
\hline
\end{tabular}

Notes: See Appendix F for assumptions. The LED fixture cost for this project is $\$ 140 /$ unit.

For the retrofit scenario, the house is assumed to start with a halogen fixture that is being replaced with the LED fixture costing \$140, so the full \$140 cost of the LED fixture is used in the calculation. Based on this unit cost and the assumed operational costs of the halogen source, the simple payback period for the LED fixture is between 10 and 17 years.

Table 3.12. Operating Costs and Payback Estimates for LED Undercabinet Fixtures: Retrofit

\begin{tabular}{|c|c|c|c|c|c|c|c|c|c|c|}
\hline \multirow[b]{2}{*}{ eW Powercore LEDs } & \multicolumn{2}{|c|}{$\begin{array}{c}\text { Energy } \\
\text { Cost/Year } \\
@ 5 c / k W h\end{array}$} & \multicolumn{2}{|c|}{$\begin{array}{c}\text { Energy } \\
\text { Cost/Year } \\
@ 11 \mathrm{c} / \mathrm{kWh}\end{array}$} & \multirow[t]{2}{*}{$\begin{array}{l}\text { Replacement } \\
\text { lamp } \\
\text { costs/year }\end{array}$} & \multicolumn{2}{|c|}{$\begin{array}{c}\text { Annual } \\
\text { Operating } \\
\text { Costs @ 5c } \\
\text { (elec + lamp) }\end{array}$} & $\begin{array}{c}\text { Annual } \\
\text { Operating } \\
\text { Costs @ 11c } \\
\text { (elec. + lamp) } \\
\end{array}$ & \multirow[t]{2}{*}{$\begin{array}{c}\text { LEDs } \\
\text { Payback @ } \\
5 \mathrm{c} / \mathrm{kWh}\end{array}$} & \multirow[t]{2}{*}{$\begin{array}{c}\text { LEDs } \\
\text { Payback @ } \\
\text { 11c/kWh }\end{array}$} \\
\hline & $\$$ & 0.37 & $\$$ & 0.80 & & $\$$ & 0.37 & $\$ \quad 0.80$ & & \\
\hline CSL Xenon Low Level & $\$$ & 2.19 & $\$$ & 4.82 & 6.12 & $\$$ & 8.31 & 10.94 & 17.6 & 13.8 \\
\hline CSL Xenon High Level & $\$$ & 3.83 & $\$$ & 8.43 & 6.12 & $\$$ & 9.95 & 14.55 & 14.6 & 10.2 \\
\hline
\end{tabular}

Notes: See Appendix F for assumptions. The LED fixture cost for this project is $\$ 140 /$ unit.

In both Table 3.11 and 3.12 paybacks are calculated based on 2 hours per day of operation. If more hours per day of operation are assumed, payback periods will shorten considerably. Table 3.13 and Table 3.14 contain the payback calculations for retrofits assuming 4 and 6 hours of use per day.

Table 3.13. Operating Costs and Payback Estimates for LED Undercabinet Fixtures: Retrofit at 4 Hours/Day Use

\begin{tabular}{|c|c|c|c|c|c|c|c|}
\hline & $\begin{array}{l}\text { Lamp } \\
\text { Watts }\end{array}$ & $\begin{array}{l}\text { Hrs/day } \\
\text { Use }\end{array}$ & $\begin{array}{c}\text { Annual } \\
\text { kWh }\end{array}$ & $\begin{array}{c}\text { Annual } \\
\text { Operating } \\
\text { Costs @ } 0 \text { c } \\
\text { (elec + lamp) }\end{array}$ & $\begin{array}{c}\text { Annual } \\
\text { Operating } \\
\text { Costs @ 11c } \\
\text { (elec. + lamp) }\end{array}$ & $\begin{array}{c}\text { LEDs } \\
\text { Payback @ } \\
\text { 5c/kWh }\end{array}$ & $\begin{array}{c}\text { LEDs } \\
\text { Payback @ } \\
\text { 11c/kWh }\end{array}$ \\
\hline eW Powercore LEDs & 10 & 4 & 14.6 & $\$ \quad 0.73$ & $\begin{array}{ll}\$ & 1.61\end{array}$ & & \\
\hline CSL Xenon Low Level & 60 & 4 & 87.6 & 10.50 & 15.76 & 14.3 & 9.9 \\
\hline CSL Xenon High Level & 105 & 4 & 153.3 & 13.79 & 22.98 & 10.7 & 6.5 \\
\hline
\end{tabular}

Notes: See Appendix F for assumptions. The LED fixture cost for this project is $\$ 140 /$ unit.

Table 3.14. Operating Costs and Payback Estimates for LED Undercabinet Fixtures: Retrofit at 6 Hours/Day Use

\begin{tabular}{|c|c|c|c|c|c|c|c|}
\hline & $\begin{array}{l}\text { Lamp } \\
\text { Watts }\end{array}$ & $\begin{array}{l}\text { Hrs/day } \\
\text { Use }\end{array}$ & $\begin{array}{c}\text { Annual } \\
\text { kWh }\end{array}$ & $\begin{array}{c}\text { Annual } \\
\text { Operating } \\
\text { Costs @ 5c } \\
\text { (elec + lamp) }\end{array}$ & $\begin{array}{c}\text { Annual } \\
\text { Operating } \\
\text { Costs @ 11c } \\
\text { (elec. + lamp) }\end{array}$ & $\begin{array}{c}\text { LEDs } \\
\text { Payback @ } \\
\text { 5c/kWh }\end{array}$ & $\begin{array}{c}\text { LEDs } \\
\text { Payback @ } \\
\text { 11c/kWh }\end{array}$ \\
\hline eW Powercore LEDs & 10 & 6 & 21.9 & $\$ \quad 1.10$ & $\$ \quad 2.41$ & & \\
\hline CSL Xenon Low Level & 60 & 6 & 131.4 & 12.69 & 20.57 & 12.1 & 7.7 \\
\hline CSL Xenon High Level & 105 & 6 & 230.0 & 17.62 & 31.41 & 8.5 & 4.8 \\
\hline
\end{tabular}

Notes: See Appendix F for assumptions. The LED fixture cost for this project is $\$ 140 /$ unit. 


\subsection{Conclusions}

The two LED-based products in this study demonstrated that they are viable alternatives to incandescent products in their intended applications, at the same time offering the potential for significant energy savings.

In the case of the downlight modules, the LR6 unit offers the potential to significantly reduce energy use while maintaining, if not improving, lighting performance when installed in the same residential downlight housings as a 75W PAR38 halogen or a 65W BR30 incandescent lamp (the LR6's intended targets). Their light output and general lighting performance were favorably received by both the host builders and other builders. With respect to their dimming performance, the issues of compatibility and appropriate application still require some attention by the manufacturer, including possibly more technical support to users. ${ }^{\text {a }}$

In the case of the Philips eW Profile LED Powercore undercabinet fixtures, they were able to meet or exceed required task lighting levels as required by the Illuminating Engineering Society of North America (IES), while offering a potential energy savings of up to $90 \%$ when compared to halogen fixtures used in the same application. In addition, their ability to render the "sparkle" factor desired by builders and customers, as well as their ability to operate coolly were favorably received by builders surveyed.

With respect to energy use, each of the LED downlight modules used in this particular study uses 63 Watts less power than the 75W PAR38, and 53 Watts less power than the 65W BR30 they replaced, providing the potential for between an $82 \%$ and $84 \%$ reduction in annual energy consumption. The Philips eW Profile LED Powercore undercabinet fixture offers the potential of a $83 \%$ to $90 \%$ annual energy reduction when compared to halogen fixtures in the same residential application, depending on the setting.

The LED sources received favorable reception from the builders who had the opportunity to compare them against incandescent and halogen sources. Close to half of the surveyed builders thought that LEDbased fixtures added to the overall value of the houses, and a number indicated their willingness to use the new light sources where it makes sense for them economically. While the survey population probably contains a higher percentage of progressive builders, these responses indicated that the installed products are performing to their expectations.

One area where the LED alternatives need to improve is cost (and they are expected to in the near future). Despite the significant reduction in annual energy consumption and maintenance cost that they can offer, the high upfront cost of these LED products and of LED products in general can be a significant barrier to their adoption, especially in the price-sensitive environment of the residential market. In choosing between a halogen lamp, an incandescent lamp, a CFL, or a LED downlight module, the simple payback of the LED downlight module used in this study would be over 7 years. To meet a simple payback of 3 years or less, the cost of an LED module would need to be less than half of the current cost.

\footnotetext{
${ }^{a}$ A more comprehensive way to address this issue of compatibility is for the industry to agree on a dimming standard.
} 
Similarly, it does not yet make sense on a solely economic basis to retrofit existing halogen and incandescent undercabinet fixtures, as the payback periods for these can be more than 10 years, especially in a low-use scenario. However, the picture is much better for replacement with LEDs at higher usage and higher electricity rates, or in the case of new construction, where only the incremental cost of the LED products, not the whole fixture cost, needs to be taken into account. At the national average electricity cost of 11 cents per kWh, the payback period for the eW Profile LED Powercore 19.25-in. fixture is currently under 5 years.

With lower product costs and possibly higher electricity rates, LEDs will certainly find favorable reception in the near future with more progressive builders and builders seeking more "green" options. Additionally, LED products with dimming capabilities can better compete, especially in applications where the baseline technology includes dimming options, as these are currently dominated by incandescent and halogen sources. As previously noted, with the rapid advancements in LED efficacy and a reduction in the cost of semi-conductors, the payback of any LED luminaire installation can be expected to improve in the future. Utility incentive programs could also help bring the initial costs down for consumers even sooner. 
Appendix A

Demonstration Homes 



\section{Appendix A}

\section{Demonstration Homes}

\begin{tabular}{|l|l|}
\hline Builder & Future B Homes \\
\hline Address & $\begin{array}{l}\text { 3333 Cooperstown Ave } \\
\text { Eugene, OR }\end{array}$ \\
\hline Type & Detached 2-story single family home with attached garage \\
\hline Size & 4127 Square feet \\
\hline Rooms & 5 Bedrooms, $3 \frac{1}{2}$ baths \\
\hline Notable features & NW ENERGY STAR Certified \\
\hline Year built & 2008 \\
\hline
\end{tabular}

Floor Plan:

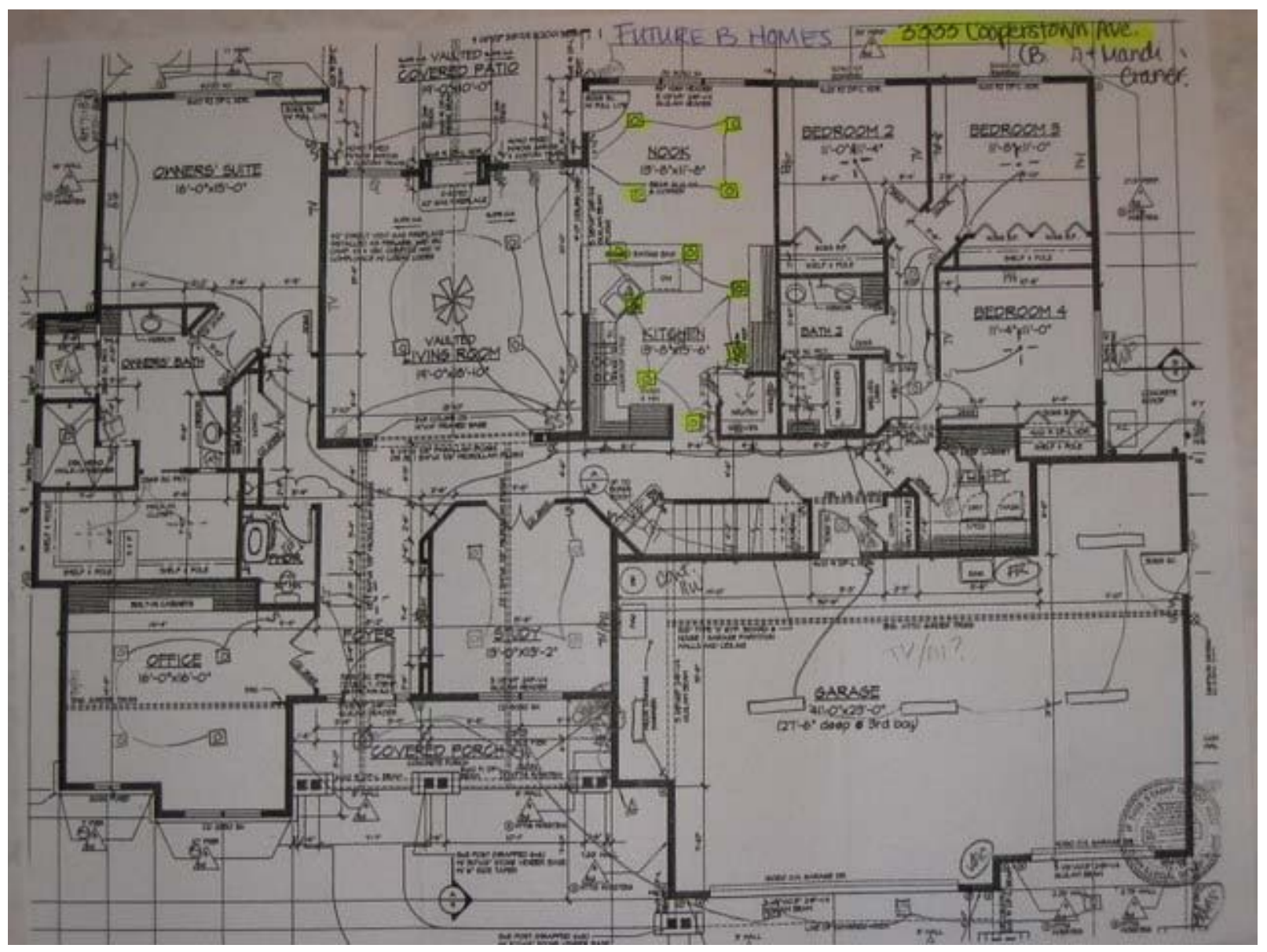




\begin{tabular}{|l|l|}
\hline Builder & $\begin{array}{l}\text { Home Builders Association of Lane County (d.b.a } \\
\text { Homebuilders Construction Company) }\end{array}$ \\
\hline Address & $\begin{array}{l}259817^{\text {th }} \text { Street } \\
\text { Springfield, OR }\end{array}$ \\
\hline Type & Detached 2-story single family home with attached garage \\
\hline Size & 2208 Square feet \\
\hline Rooms & 4 Bedrooms, $2 \frac{1}{2}$ baths \\
\hline Notable features & $\begin{array}{l}\text { NW ENERGY STAR and Earth Advantage certified, } \\
\text { photovoltaic panels. }\end{array}$ \\
\hline Year built & 2008 \\
\hline
\end{tabular}

Floor Plan, 1st floor:

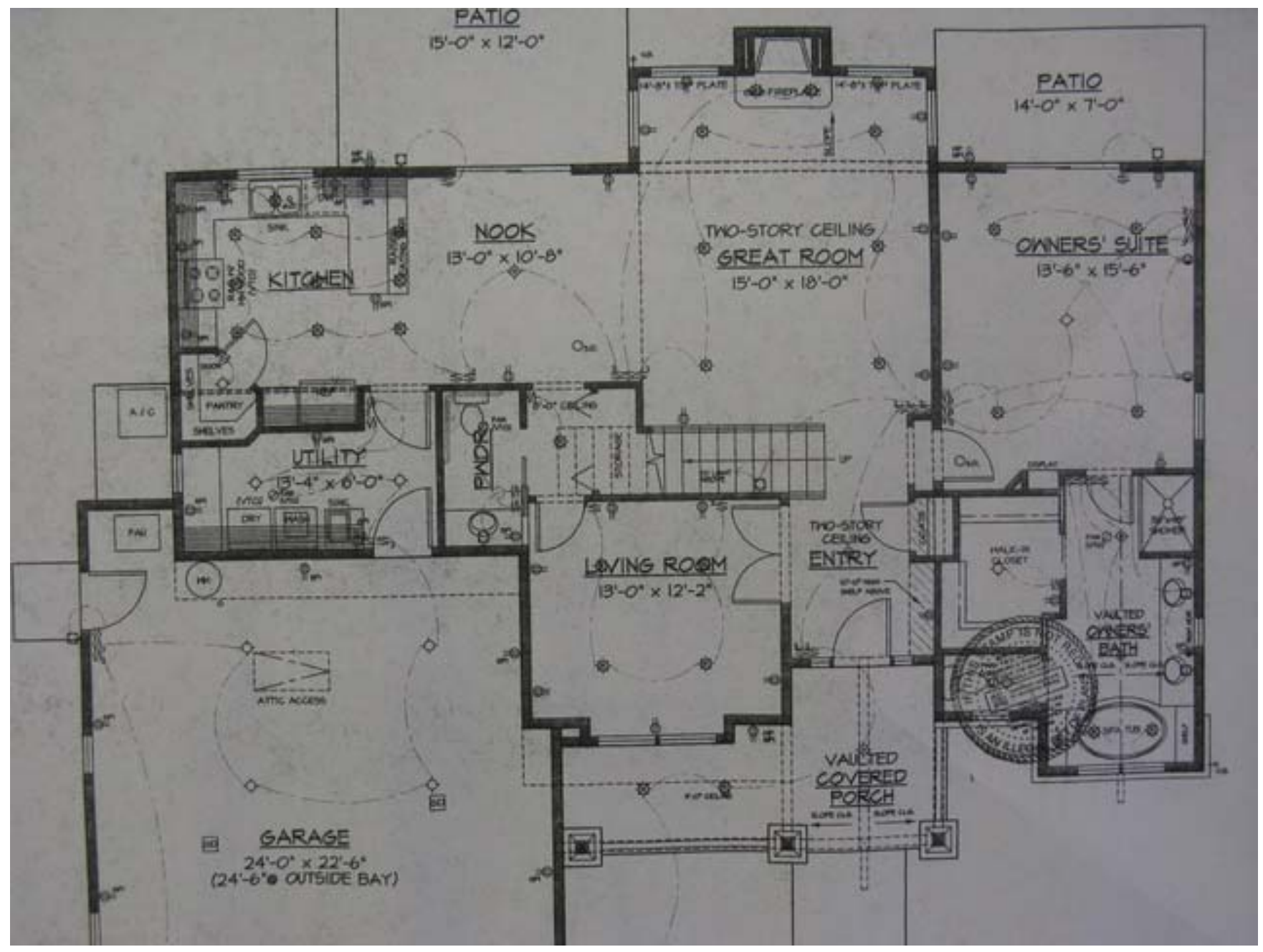


Appendix B

\section{Measurement Equipment \& Conditions}





\section{Appendix B \\ Measurement Equipment \& Conditions}

Date: June 11 \& 12, 2008

Time: 9:45 PM - 2:30 AM

Temperature: $70 \mathrm{~F}$

Conditions: Indoor, controlled conditions

\begin{tabular}{|l|l|}
\hline Illuminance Meter & Minolta Illuminance Meter, Model T-1 \\
\hline Chroma Meter & Konica Minolta Chroma Meter, Model CL-200 \\
\hline Power Meter & N/A \\
\hline Temperature Meter & Honeywell T8812 \\
\hline
\end{tabular}


B. 2 


\section{Appendix C}

\section{Illuminance-Level Measurement Data}





\section{Appendix C}

\section{Illuminance-Level Measurement Data}

Illuminance Level Measurements: Raw Data - HBA Home

\begin{tabular}{|c|c|c|}
\hline \multicolumn{3}{|c|}{$\begin{array}{l}\text { Downlight } \\
\text { Kitchen Floor (fc) }\end{array}$} \\
\hline 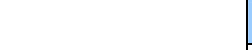 & BR30 & LR6 \\
\hline & 9.5 & 10.4 \\
\hline & 9 & 10.6 \\
\hline & 10.1 & 12 \\
\hline & 8.9 & 10.2 \\
\hline & 8.6 & 10.1 \\
\hline Average & 9.2 & 10.7 \\
\hline $\operatorname{Max}$ & 10.1 & 12.0 \\
\hline Min & 8.6 & 10.1 \\
\hline Max/Min & 1.2 & 1.2 \\
\hline
\end{tabular}

Downlight

Living Space (fc)

\begin{tabular}{|l|l|} 
BR30 & LR6 \\
\hline
\end{tabular}

$2.7 \quad 3.8$

$2.9 \quad 4$

$2.8 \quad 3.8$

$2.6 \quad 3.7$

34

3.14 .1

$3.2 \quad 4.2$

34

$3.2 \quad 4.2$

$3.4 \quad 4.4$

$3.4 \quad 4.3$

$3.2 \quad 4.1$

$3.3 \quad 4.2$

$3.4 \quad 4.3$

$3.4 \quad 4.4$

$3.3 \quad 4.2$

$3.2 \quad 4$

$3.2 \quad 4.2$

$3.3 \quad 4.2$

\begin{tabular}{|r|r|r|} 
& 3.3 & 4.2 \\
\hline Average & 3.3 & 4 \\
\hline Max & 3.1 & 4.1 \\
\hline Min & $\mathbf{3 . 4}$ & 4.4 \\
\hline Max/Min & 3.4 & 3.7 \\
\hline
\end{tabular}

Downlight

Kitchen Counter (fc)

\begin{tabular}{|c|c|c|}
\hline & BR30 & LR6 \\
\hline & 11.3 & 14.2 \\
\hline & 11.2 & 14.5 \\
\hline & 13.0 & 14.3 \\
\hline & 12.6 & 13.8 \\
\hline & 9.3 & 11.2 \\
\hline & 13.0 & 14.7 \\
\hline & 12.5 & 15.1 \\
\hline & 11.3 & 14.6 \\
\hline & 10.9 & 13.7 \\
\hline & 8.8 & 11.7 \\
\hline & 9.5 & 12.4 \\
\hline & 9.9 & 13.0 \\
\hline & 9.5 & 13.1 \\
\hline & 9.4 & 12.8 \\
\hline & 6.9 & 10.4 \\
\hline & 6.9 & 10.6 \\
\hline & 7.0 & 10.5 \\
\hline & 6.2 & 9.3 \\
\hline & 5.0 & 8.3 \\
\hline $\begin{array}{r}\text { Max light level at } \\
\text { counter (fc) }\end{array}$ & 13.0 & 15.1 \\
\hline $\begin{array}{r}\text { Min light level at } \\
\text { counter (fc) }\end{array}$ & 5.0 & 8.3 \\
\hline Avg light level (fc) & 9.7 & 12.5 \\
\hline Max/Min & 2.6 & 1.8 \\
\hline
\end{tabular}




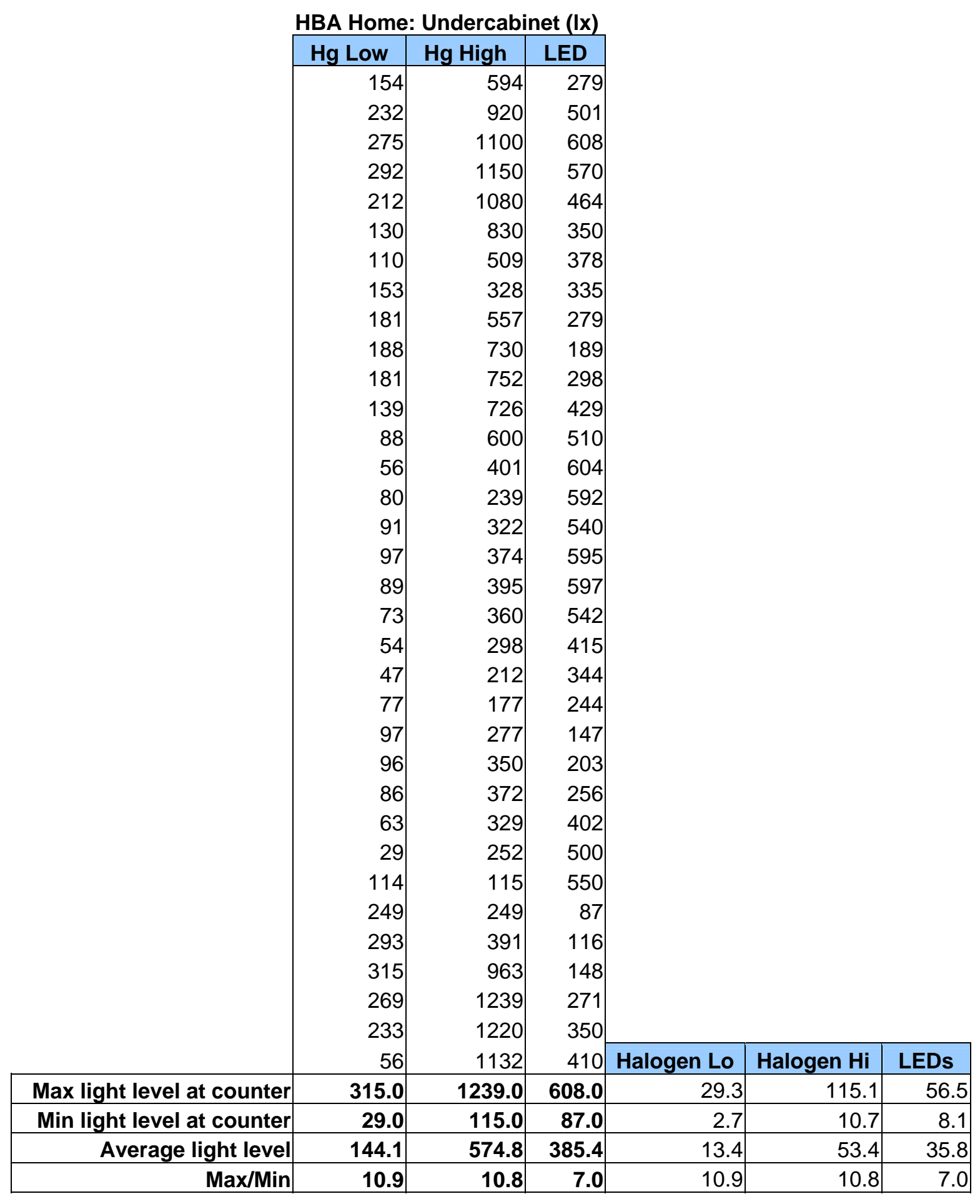


Illuminance Level Measurements: Raw Data - Future B Homes

\begin{tabular}{|c|c|c|c|c|c|}
\hline \multicolumn{3}{|c|}{$\begin{array}{l}\text { Downlight } \\
\text { Kitchen \& Dining Room Floor (fc) }\end{array}$} & & \multicolumn{2}{|c|}{$\begin{array}{l}\text { Downlight } \\
\text { Counter Height (fc) }\end{array}$} \\
\hline & 75W R38 & LR6 & & 75W R38 & LR6 \\
\hline & 10 & 11 & & 7.3 & 8.6 \\
\hline & 11.6 & 12.9 & & 9.7 & 10.4 \\
\hline & 11.7 & 13.6 & & 11.5 & 12.1 \\
\hline & 11 & 12.9 & & 11.5 & 13.8 \\
\hline & 10.5 & 12.7 & & 11.3 & 14.7 \\
\hline & 12.2 & 14.2 & & 11.5 & 14.5 \\
\hline & 12.4 & 14.2 & & 13.1 & 15.1 \\
\hline & 12 & 13.4 & & 15.5 & 17.1 \\
\hline & 9.3 & 10.5 & & 14.1 & 18.9 \\
\hline & 7.2 & 9.7 & & 14.8 & 19.1 \\
\hline & 9.6 & 11.2 & & 14.6 & 17.3 \\
\hline & 10.6 & 11.8 & & 13.3 & 16.7 \\
\hline & 9.7 & 11.1 & & 14.5 & 15.1 \\
\hline & 7.2 & 9.4 & & 9.9 & 11.2 \\
\hline & 8.2 & 10.4 & & 10.2 & 12.2 \\
\hline & 10.4 & 12.4 & & 9.3 & 11.4 \\
\hline & 11.1 & 13.2 & Average & 12.0 & 14.3 \\
\hline & 10.6 & 12.6 & $\operatorname{Max}$ & 15.5 & 19.1 \\
\hline & 8.3 & 10.8 & Min & 7.3 & 8.6 \\
\hline & 7.3 & 8.9 & Max/Min & 2.1 & 2.2 \\
\hline & 8.4 & 10.1 & & & \\
\hline & 8.1 & 10.5 & & & \\
\hline & 9.2 & 12.4 & & & \\
\hline & 7.1 & 10.6 & & & \\
\hline & 8.5 & 11.6 & & & \\
\hline & 7 & 9.6 & & & \\
\hline Average & 9.6 & 11.6 & & & \\
\hline $\operatorname{Max}$ & 12.4 & 14.2 & & & \\
\hline Min & 7 & 8.9 & & & \\
\hline Max/Min & 1.8 & 1.6 & & & \\
\hline
\end{tabular}




$$
\text { C. } 4
$$


Appendix D

Test Results for Philips eW $®$ Profile Powercore Undercabinet Fixture from Independent Laboratory 



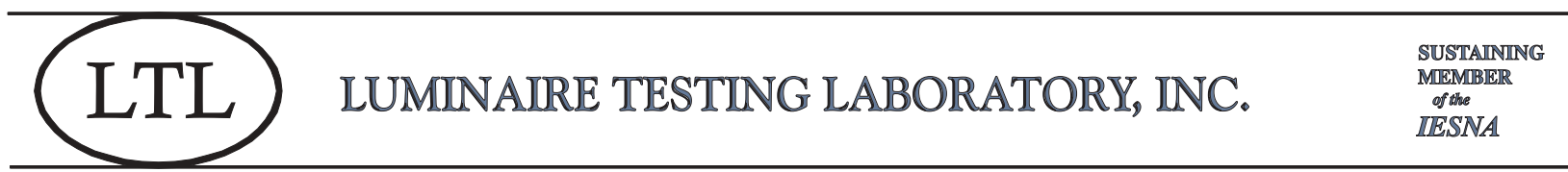

905 Harrison Street • Allentown, PA 18103 • 610-770-1044 • Fax 610-770-8912 - www.LuminaireTesting.com

LTL NUMBER: 13714

DATE : $08-27-2008$

PREPARED FOR: PACIFIC NORTHWEST NATIONAL LABORATORY/BATTELLE

CATALOG NUMBER: CALIPER 08-89

LUMINAIRE: EXTRUDED ALUMINUM HOUSING WITH FORMED PLASTIC ENDS, FROSTED PLASTIC ENCLOSURE.

LAMPS : 10 WHITE LEDS

LED POWER SUPPLY: ONE UNMARKED LED POWER SUPPLY

ELECTRICAL VALUES: 120.0VAC, $0.0828 \mathrm{~A}, 9.89 \mathrm{~W}$

LUMINAIRE EFFICACY: 28.0 LUMENS/WATT

NOTE: THIS TEST WAS PERFORMED USING THE CALIBRATED PHOTODETECTOR METHOD OF ABSOLUTE PHOTOMETRY . *

VERTICAL TEST DATA WAS ACQUIRED IN 1/2 DEGREE INCREMENTS .

LUMINAIRE STANDARD CANDELA DISTRIBUTION

$\begin{array}{rrrr}\text { VER } & \text { LATERAL } & \text { ANGLE } & \\ \text { ANG } & 0.0 & 22.5 & 45.0 \\ 0 & 98 & 98 & 98 \\ 5 & 100 & 100 & 99 \\ 15 & 104 & 103 & 100 \\ 25 & 104 & 102 & 98 \\ 35 & 101 & 98 & 92 \\ 45 & 93 & 91 & 83 \\ 55 & 82 & 78 & 70 \\ 65 & 70 & 64 & 52 \\ 75 & 57 & 51 & 36 \\ 85 & 22 & 19 & 15 \\ 90 & 13 & 11 & 8 \\ 95 & 8 & 7 & 5 \\ 105 & 3 & 2 & 2 \\ 115 & 1 & 1 & 0 \\ 125 & 0 & 0 & 0 \\ 135 & 0 & 0 & 0 \\ 145 & 0 & 0 & 0 \\ 155 & 0 & 0 & 0 \\ 165 & 0 & 0 & 0 \\ 175 & 0 & 0 & 0 \\ 180 & 0 & 0 & 0\end{array}$

$\begin{array}{rr}675 & 90.0 \\ 98 & 98 \\ 99 & 98 \\ 97 & 94 \\ 92 & 87 \\ 83 & 76 \\ 71 & 61 \\ 55 & 42 \\ 37 & 22 \\ 18 & 8 \\ 7 & 1 \\ 4 & 0 \\ 2 & 0 \\ 0 & 0 \\ 0 & 0 \\ 0 & 0 \\ 0 & 0 \\ 0 & 0 \\ 0 & 0 \\ 0 & 0 \\ 0 & 0 \\ 0 & 0\end{array}$

112.5
98
97
90
81
67
50
32
17
6
1
0
0
0
0
0
0
0
0
0
0
0

135.0

98
95
87
74
58
42
27
12
4
1
0
0
0
0
0
0
0
0
0
0
0

ZONAL

LUMEN

SUMS

$$
\begin{array}{r}
9 \\
26 \\
40 \\
47 \\
48 \\
42 \\
31 \\
21 \\
8 \\
3 \\
1 \\
0 \\
0 \\
0 \\
0 \\
0 \\
0 \\
0
\end{array}
$$

ZONAL LUMEN SUMMARY DATA IN MAJOR ZONES

$\begin{array}{rrr}\text { ZONE } & \text { LUMENS } & \text { \%FIXT } \\ 0-30 & 75 & 27.23 \\ 0-40 & 123 & 44.31 \\ 0-60 & 213 & 76.94 \\ 0-90 & 273 & 98.61 \\ 90-120 & 4 & 1.33 \\ 90-130 & 4 & 1.35 \\ 90-150 & 4 & 1.37 \\ 90-180 & 4 & 1.39 \\ 0-180 & 277 & 100.00\end{array}$

TOTAL LUMEN OUTPUT: 277 CIE CLASSIFICATION TYPE DIMENSION NORMAL TO O-DEG PLANE 19.000" DIMENSION PARALLEL 0-DEG PLANE 1.125"

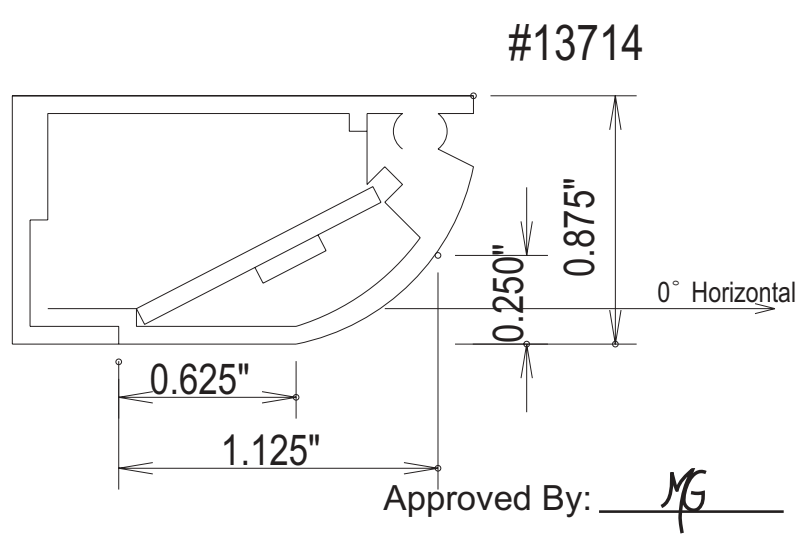

*DATA WAS ACQUIRED USING THE CALIBRATED PHOTODETECTOR METHOD OF ABSOLUTE PHOTOMETRY. A UDT MODEL \#211 PHOTODETECTOR AND UDT MODEL \#S370 OPTOMETER COMBINATION WERE USED AS A STANDARD. A SPECTRAL MISMATCH CORRECTION FACTOR WAS EMPLOYED BASED ON THE SPECTRAL RESPONSIVITY OF THE PHOTODETECTOR AND THE SPECTRAL POWER DISTRIBUTION OF THE TEST SUBJECT.

TESTING WAS PERFORMED IN ACCORDANCE WITH IES LM-79-08.

TEST ANGULAR INCREMENTS AND REPORT FORMATTING WAS BASED ON IES LM-41-98 AND LM-46-04. 


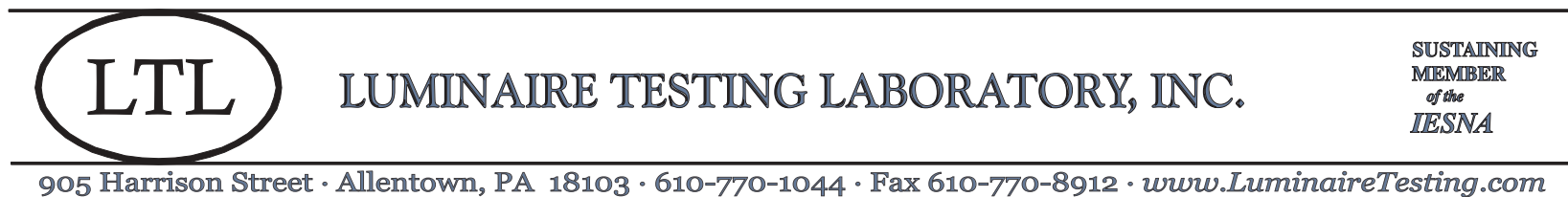

905 Harrison Street · Allentown, PA 18103 - 610-770-1044 • Fax 610-770-8912 - www.LuminaireTesting .com

LTL NUMBER: 13714

PREPARED FOR: PACIFIC NORTHWEST NATIONAL LABORATORY/BATTELLE

DATE : $08-27-2008$
LUMINANCE IN CANDELA PER SQUARE METER VER LATERAL ANGLE

$\begin{array}{rrrr}\text { ANG } & \text { LATERAL ANGLE } & \\ 0 & 0-D E G & 45-D E G & 90-D E G \\ 45 & 7104 & 7104 & 7104 \\ 55 & 7861 & 7329 & 6252 \\ 65 & 7847 & 7204 & 5355 \\ 75 & 8110 & 6722 & 3814 \\ 85 & 8769 & 6383 & 2288 \\ & 5269 & 4389 & 1191\end{array}$

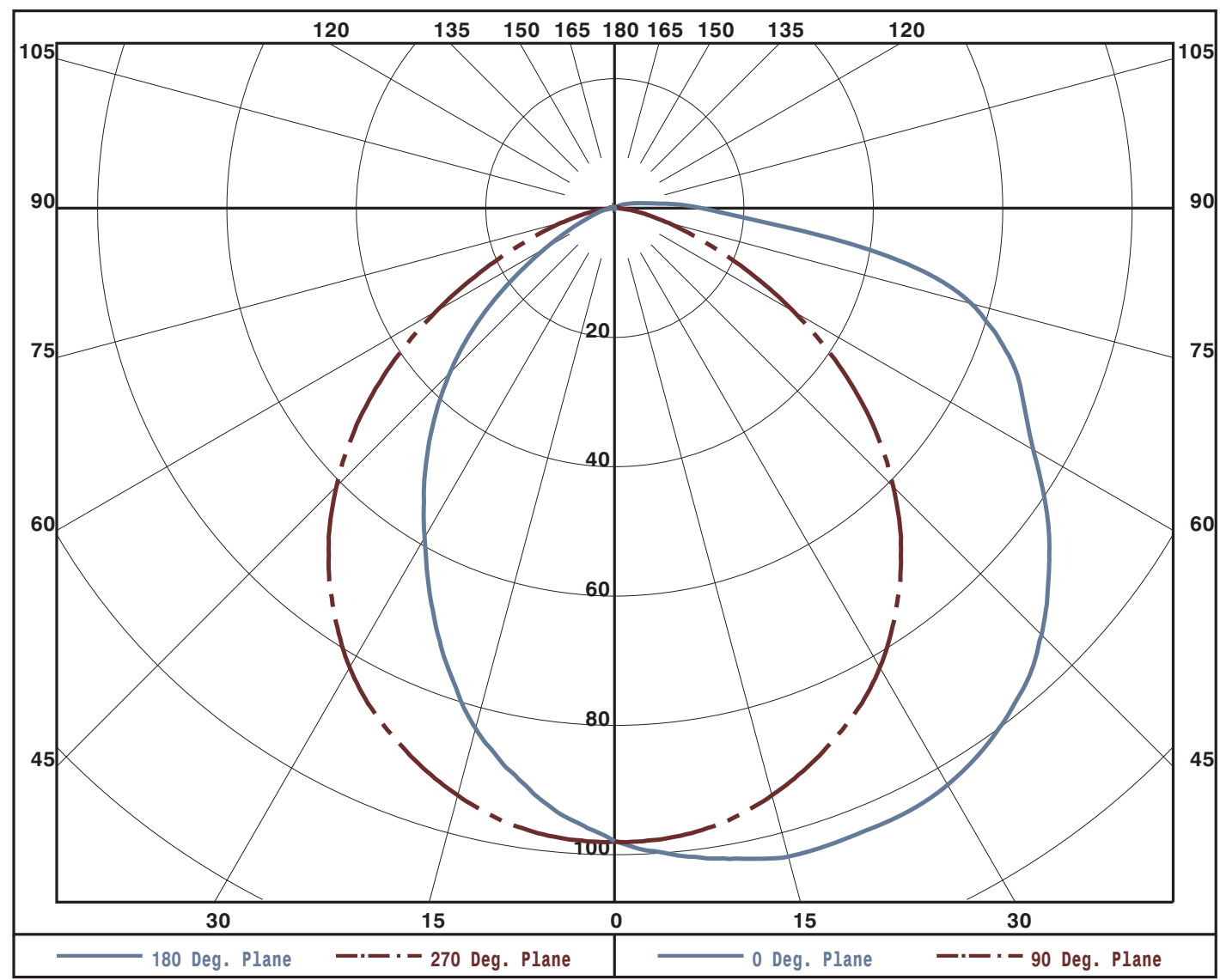




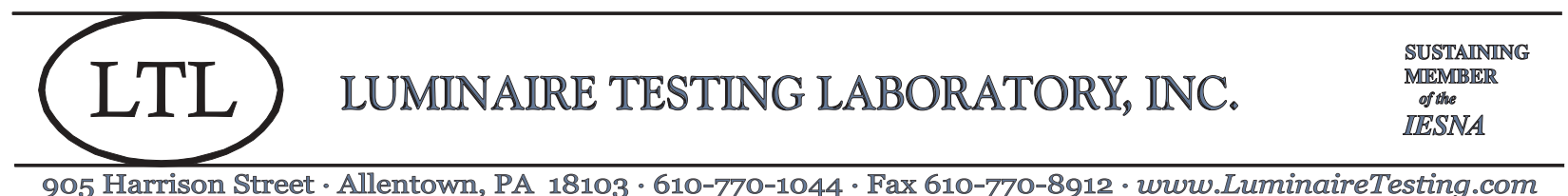

905 Harrison Street · Allentown, PA 18103 - 610-770-1044 · Fax 610-770-8912 - www.LuminaireTesting.com

LTL NUMBER: 13714

DATE: $08-27-2008$

PREPARED FOR: PACIFIC NORTHWEST NATIONAL LABORATORY/BATTELLE

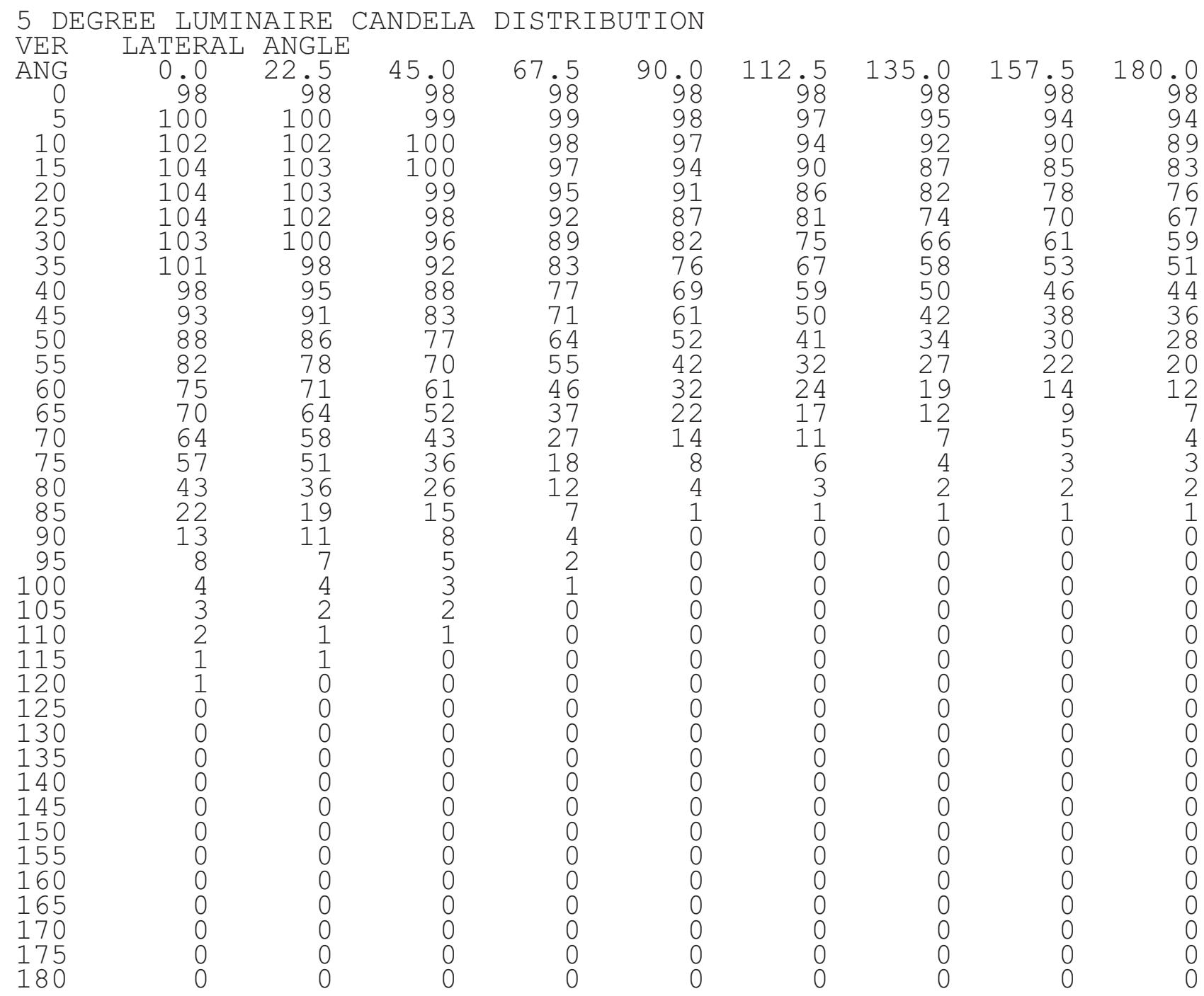

THIS TEST WAS CONDUCTED USING PHOTOMETRY TECHNIQUES ACCORDING TO STANDARD IES PROCEDURES. THE USER MUST THEREFORE USE CAUTION IN THE FOLLOWING SITUATIONS: 1) THIS TEST WAS PERFORMED USING A SPECIFIC BALLAST/LAMP COMBINATION. EXTRAPOLATION OF THESE DATA FOR OTHER BALLAST/LAMP COMBINATIONS MAY PRODUCE ERRONEOUS RESULTS. $\quad 2)$ THIS TEST WAS CONDUCTED IN A CONTROLLED LABORATORY ENVIRONMENT WHERE THE AMBIENT TEMPERATURE WAS HELD AT $25^{\circ} \mathrm{C} \pm 1^{\circ} \mathrm{C}$. FIELD PERFORMANCE MAY DIFFER PARTICULARLY IN REGARDS TO CHANGE IN LUMINOUS OUTPUT AS A RESULT OF DIFFERENCE IN AMBIENT TEMPERATURE AND METHOD OF MOUNTING THE LUMINAIRE. 


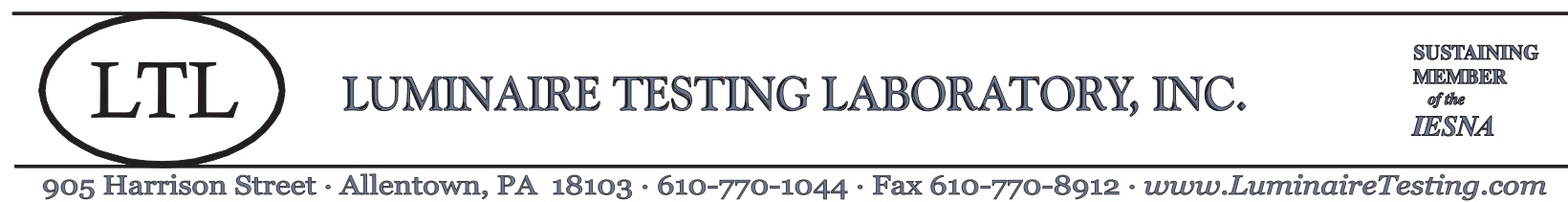

905 Harrison Street · Allentown, PA 18103 • 610-770-1044 · Fax 610-770-8912 - www.LuminaireTesting.com

ISOFOOTCANDLE CONVERSION FACTORS FOR SELECTED MOUNTING HEIGHTS

\begin{tabular}{|l|c|c|c|c|c|}
\hline MOUNTING HEIGHT & $1^{\prime}$ & $1.5^{\prime}$ & $2^{\prime}$ & $2.5^{\prime}$ & $3^{\prime}$ \\
\hline MULTIPLIER & 4.00 & 1.78 & 1.00 & 0.64 & 0.44 \\
\hline
\end{tabular}

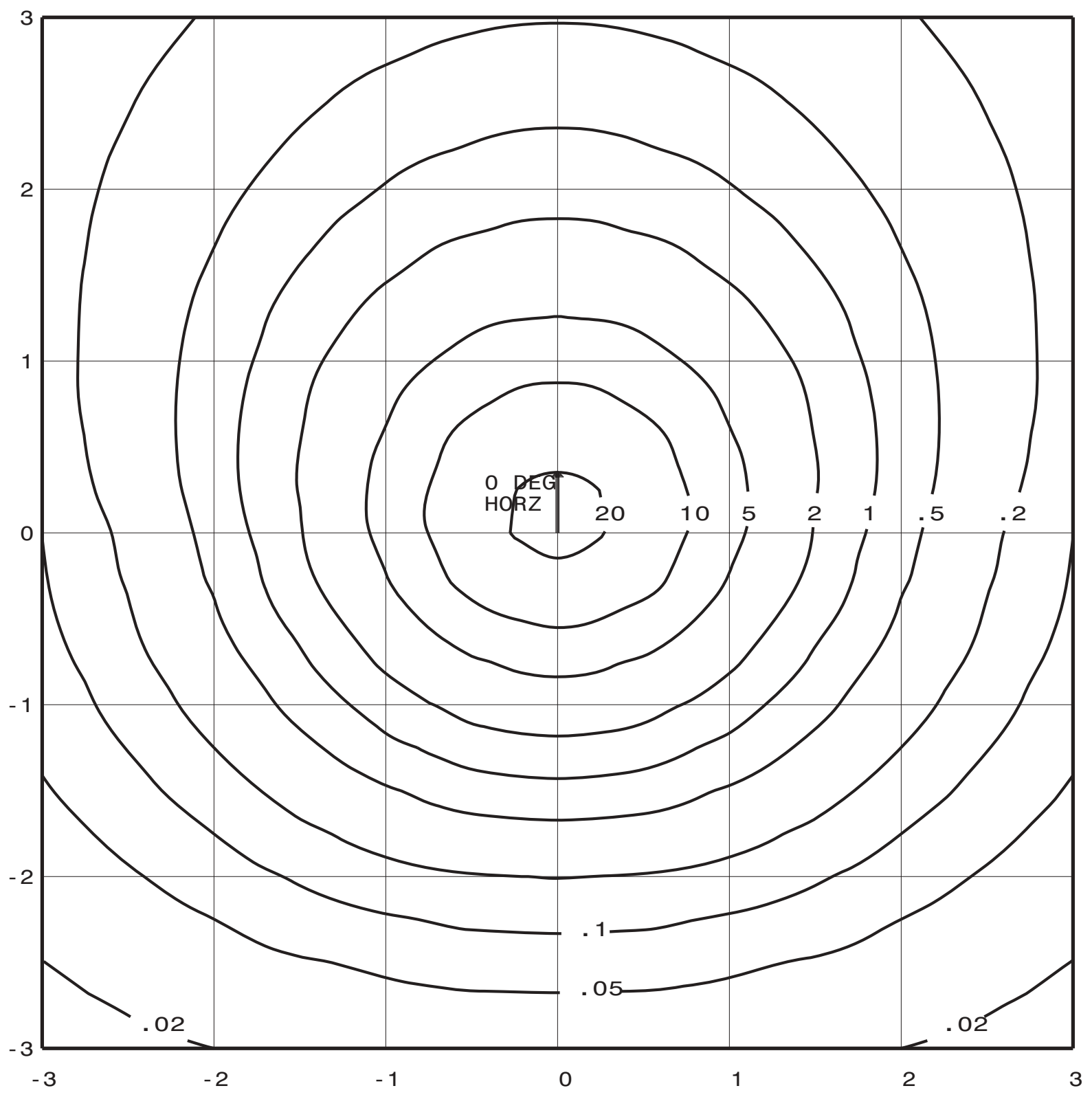

LTL REPORT NUMBER 13714 -ISOFOOTCANDLE VALUES ARE BASED ON A MOUNTING HEIGHT OF 2', WITH THE LUMINAIRE LOCATED AT 0,0. ISOFOOTCANDLE VALUES ARE CALCULATED FROM THE DIRECT CONTRIBUTION FROM THE LUMINAIRE ONLY. WALL, CEILING, AND FLOOR CONTRIBUTION IS NOT INCLUDED. 


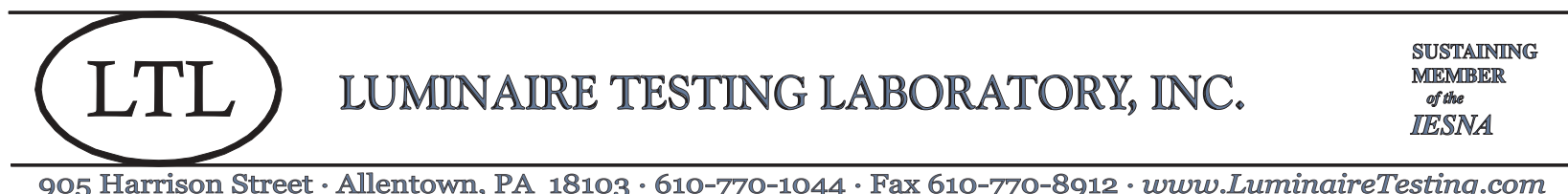

905 Harrison Street • Allentown, PA 18103 · 610-770-1044 · Fax 610-770-8912 - www.LuminaireTesting .com

LTL NUMBER: 13714

DATE: $08-27-2008$

PREPARED FOR: PACIFIC NORTHWEST NATIONAL LABORATORY/BATTELLE

CATALOG NUMBER: CALIPER 08-89

LUMINAIRE: EXTRUDED ALUMINUM HOUSING WITH FORMED PLASTIC ENDS, FROSTED PLASTIC ENCLOSURE.

LAMPS : 10 WHITE LEDS

LED POWER SUPPLY: ONE UNMARKED LED POWER SUPPLY

PROCEDURE: ALL TESTING WAS PERFORMED IN THE LTL PHOTOMETRIC TESTING LABORATORY WITH A CONTROLLED THERMAL ENVIRONMENT OF $25.0^{\circ} \mathrm{C} \pm 0.5^{\circ} \mathrm{C}$. THERMOCOUPLE LEADS WERE ATTACHED TO TWO LOCATIONS ON THE LAMP (SEE DIAGRAM BELOW). TEMPERATURE MEASUREMENTS WERE ACQUIRED USING A YOKOGAWA 2423A THERMOMETER

DATA :

\begin{tabular}{|ll|l|}
\hline & TEMPERATURE \\
\hline LOCATION \#1 ON LUMINAIRE & $36.3^{\circ} \mathrm{C}$ \\
\hline LOCATION \#2 ON LUMINAIRE & $46.2^{\circ} \mathrm{C}$ \\
\hline
\end{tabular}
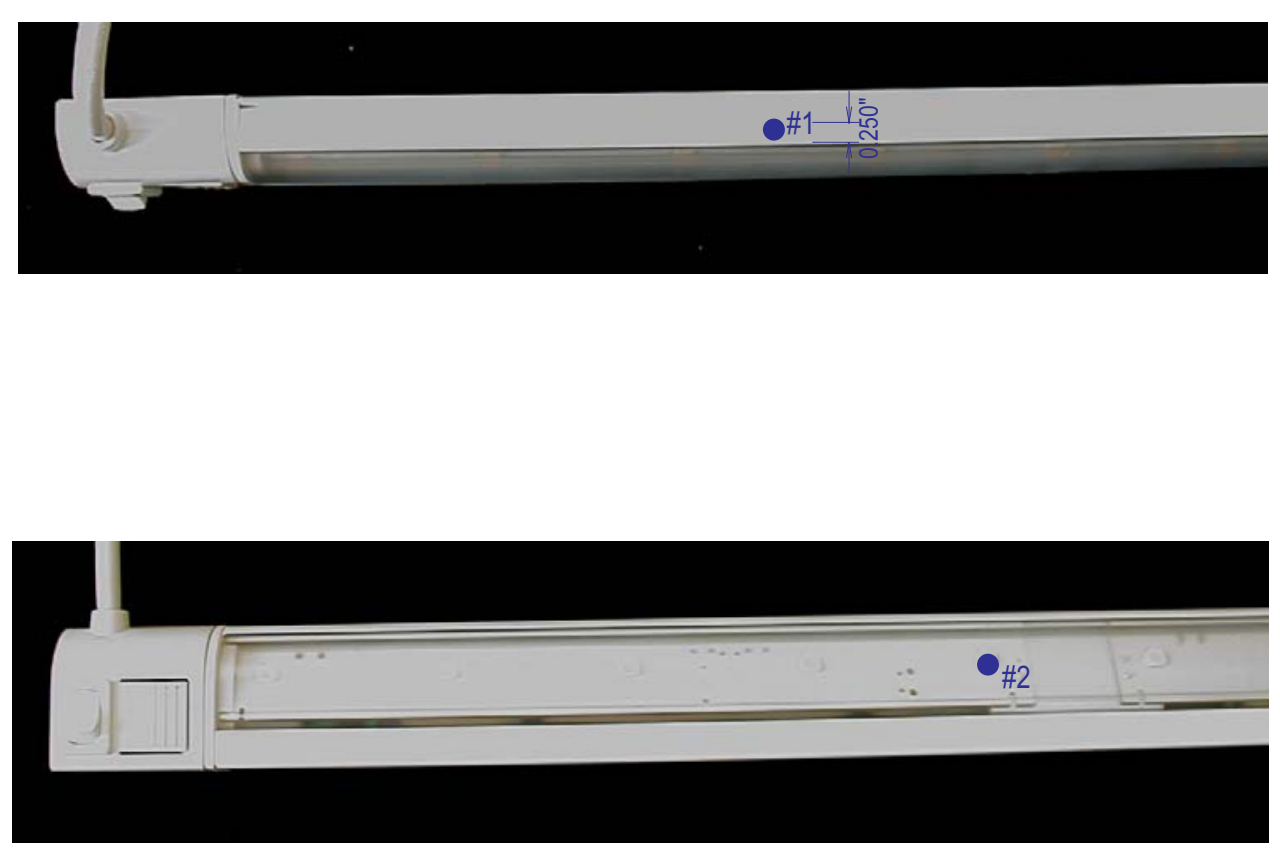

"OFF" POWER ELECTRICAL READINGS: 120.0VAC, 0.00A, 0.00W 


\section{LTL LUMINAIRE TESTING LABORATORY, INC.}

LTL Number: 13715

Date: 08-28-2008

Prepared For: Pacific Northwest National Laboratory/Battelle

PNNL Catalog Number: CALiPER 08-89

Luminaire: Extruded aluminum housing with formed plastic ends, frosted plastic enclosure.

Lamp: 10 White LEDs

LED Power Supply: One unmarked LED power supply

Lamp Efficacy: 28.4 Lumens/Watt

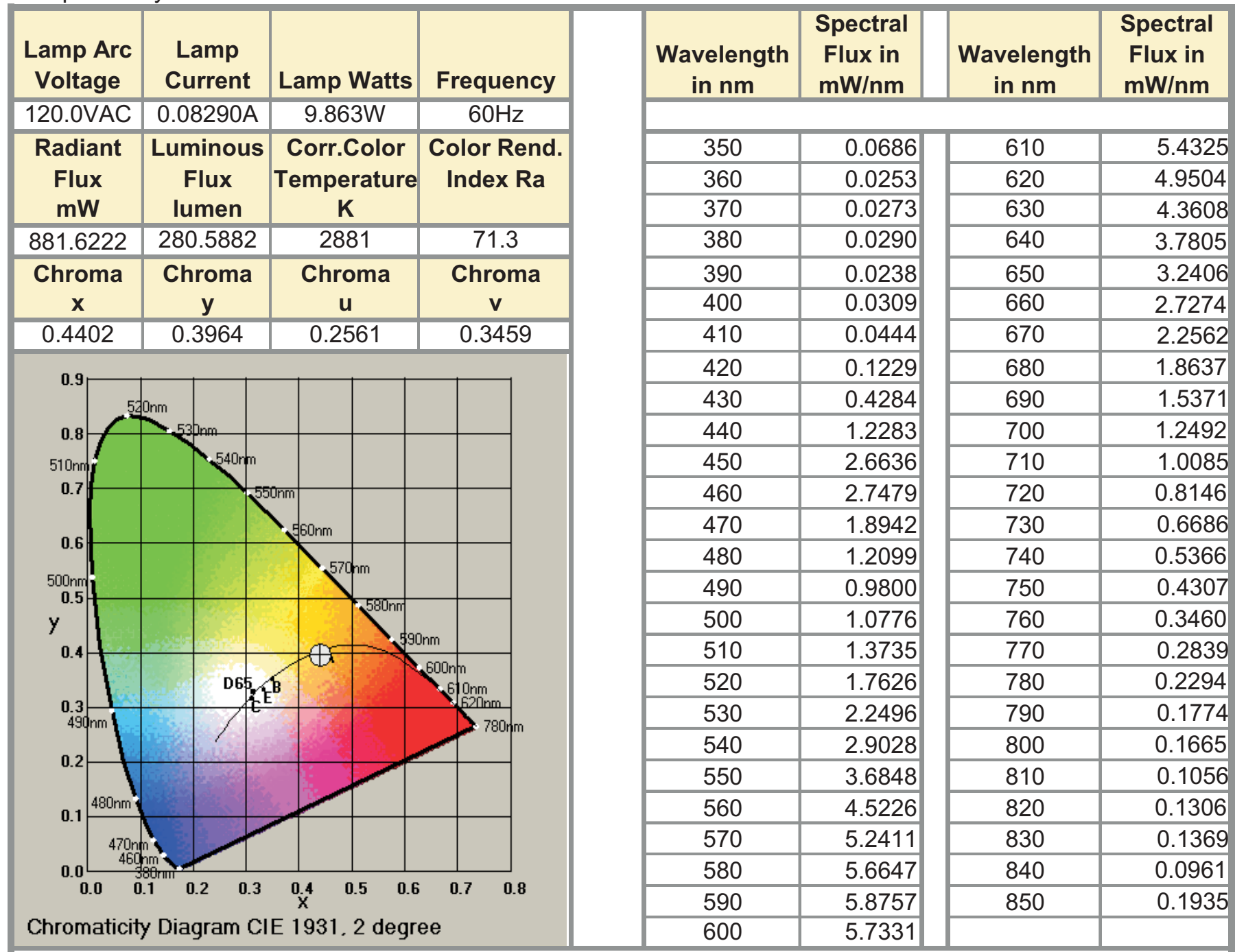

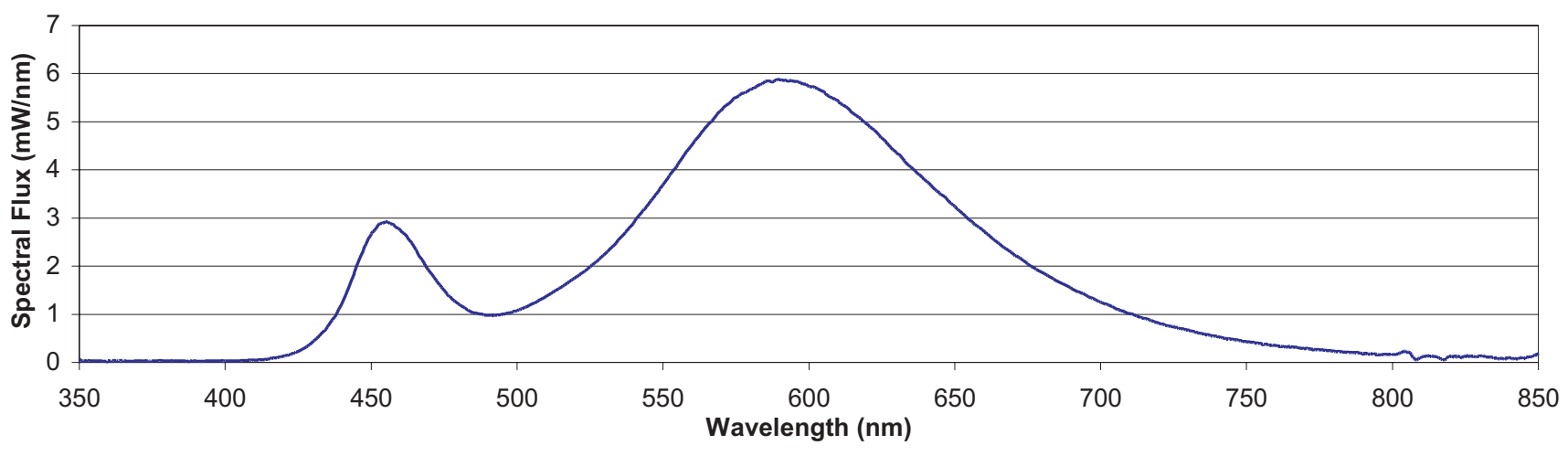


Appendix E Questionnaire of Builders' Perception of LED Lighting 



\section{Appendix E}

\section{Questionnaire of Builders' Perception of LED Lighting}

\section{Lighting Questionnaire}

Alternative types of light fixtures (LEDs) were recently installed in the HBA and Future B homes for the 2008 Tour of Homes. The U.S. Department of Energy is interested in your opinions of these new products and has constructed a brief questionnaire to obtain your feedback. The questionnaire is entirely voluntary. Your responses will be aggregated with those of others via computer and no individual responses or other identification will be reported.

1. Did you notice that new lighting fixtures were used in the kitchen and dining room at the Future B home?

$$
\text { Yes No }
$$

2. Did you notice that new fixtures were used in the kitchen and dining room, and also under cabinets at the HBA home?

Kitchen/Dining: $\quad$ Yes No Under Cabinet: Yes No

NOTE: Answer Q3-Q9 ONLY IF YES IN Q1 and/or Q2. Put an " $X$ " in the appropriate column.

\begin{tabular}{|c|c|c|c|c|c|}
\hline \multirow{2}{*}{ Questions: Appearance } & More & \multicolumn{3}{|c|}{ About the Same } & \multirow{2}{*}{$\begin{array}{ll}\text { Less } \\
5\end{array}$} \\
\hline & 1 & 2 & \begin{tabular}{l|l}
3 \\
\end{tabular} & 4 & \\
\hline $\begin{array}{l}\text { 3. Do you feel that the LED light fixtures provide more, } \\
\text { less, or just the right amount of light compared to what } \\
\text { you are used to? }\end{array}$ & & & & & \\
\hline Future B Home: Kitchen Dining & & & & & \\
\hline HBA Home: Kitchen/Dining & & & & & \\
\hline HBA Home: Under Cabinet & & & & & \\
\hline $\begin{array}{l}\text { 4. Do you feel that the LED light fixtures create more, } \\
\text { less or about the same amount of shadows? }\end{array}$ & & & & & \\
\hline Future B Home: Kitchen Dining & & & & & \\
\hline HBA Home: Kitchen/Dining & & & & & \\
\hline HBA Home: Under Cabinet & & & & & \\
\hline $\begin{array}{l}\text { 5. Do you feel that the new LED light fixtures create } \\
\text { more, less or about the same amount of glare? }\end{array}$ & & & & & \\
\hline Future B Home: Kitchen Dining & & & & & \\
\hline HBA Home: Kitchen/Dining & & & & & \\
\hline HBA Home: Under Cabinet & & & & & \\
\hline
\end{tabular}




\begin{tabular}{|c|c|c|c|c|c|}
\hline \multirow[t]{2}{*}{ Questions: Value } & \multicolumn{5}{|c|}{ Positive Impact } \\
\hline & 1 & 2 & 3 & 4 & 5 \\
\hline $\begin{array}{l}\text { 6. Do you notice that the new LED lighting had a } \\
\text { positive, negative, or neutral impact on overall visibility } \\
\text { in the area where they were installed? }\end{array}$ & & & & & \\
\hline Future B Home: Kitchen Dining & & & & & \\
\hline HBA Home: Kitchen/Dining & & & & & \\
\hline HBA Home: Under Cabinet & & & & & \\
\hline $\begin{array}{l}\text { 7. Do you feel the new LED light fixtures have had a } \\
\text { positive, negative, or neutral impact on the overall } \\
\text { appearance of the homes? }\end{array}$ & & & & & \\
\hline Future B Home: Kitchen Dining & & & & & \\
\hline HBA Home: Kitchen/Dining & & & & & \\
\hline HBA Home: Under Cabinet & & & & & \\
\hline $\begin{array}{l}\text { 8. Do you feel the new LED light fixtures have a positive, } \\
\text { negative, or neutral impact on the overall value of the } \\
\text { homes? }\end{array}$ & & & & & \\
\hline Future B Home: Kitchen Dining & & & & & \\
\hline HBA Home: Kitchen/Dining & & & & & \\
\hline HBA Home: Under Cabinet & & & & & \\
\hline
\end{tabular}

\begin{tabular}{|c|c|c|c|c|c|}
\hline \multirow{2}{*}{ Question: Preference } & New & \multicolumn{3}{|c|}{ About the Same } & \multirow{2}{*}{$\begin{array}{l}\text { Old } \\
5\end{array}$} \\
\hline & 1 & 2 & 3 & 4 & \\
\hline $\begin{array}{l}\text { 9. When all things are considered, do you prefer the new } \\
\text { light LED fixtures that were installed or do you prefer } \\
\text { the fixtures you currently use? }\end{array}$ & & & & & \\
\hline Future B Home: Kitchen Dining & & & & & \\
\hline HBA Home: Kitchen/Dining & & & & & \\
\hline HBA Home: Under Cabinet & & & & & \\
\hline
\end{tabular}

10. Explain why do you prefer the light fixtures you selected in the last question? (Skip if no preference.)

a. New (LED) fixtures

b. Old fixtures

11. Do you plan to offer any of the alternative LED fixtures in the homes you build in the future? (circle one)

Yes No Maybe 
12. Please indicate current lamp/fixture types you are using (incandescent, CFL, or LEDs): Kitchen: Dining:

Under Cabinet:

\section{Any other comments?}

Tallied Results:

\section{Thank you for your time!}

\begin{tabular}{|c|c|c|c|c|c|c|}
\hline \multicolumn{6}{|c|}{ Brightness, Shadow and Glare } & \multirow[b]{2}{*}{ Total } \\
\hline Light level with LEDs & More & & Same & & Less & \\
\hline Future B Homes kitchen \& dining & 4 & & 2 & & & 6 \\
\hline Lane County HBA kitchen \& living & & 7 & 3 & 2 & & 12 \\
\hline Lane County HBA undercabinet & & 2 & 4 & 6 & & 12 \\
\hline & & & & & & \\
\hline \multicolumn{7}{|l|}{ Shadow amount with LEDs } \\
\hline Future B Homes kitchen \& dining & & 2 & 2 & 1 & 1 & 6 \\
\hline Lane County HBA kitchen \& living & & 4 & 5 & 2 & 1 & 12 \\
\hline Lane County HBA undercabinet & & 2 & 6 & 2 & 2 & 12 \\
\hline \multicolumn{7}{|l|}{ Glare amount with LEDs } \\
\hline Future B Homes kitchen \& dining & & 2 & 2 & 2 & & 6 \\
\hline Lane County HBA kitchen \& living & & 2 & 3 & 5 & 2 & 12 \\
\hline Lane County HBA undercabinet & & 2 & 2 & 6 & 2 & 12 \\
\hline \multicolumn{7}{|c|}{ Visibility, Appearance and Value } \\
\hline Overall visibility & More & & Same & & Less & Total \\
\hline Future B Homes kitchen \& dining & 3 & 1 & 2 & & & 6 \\
\hline Lane County HBA kitchen \& living & 4 & 2 & 4 & 2 & & 12 \\
\hline Lane County HBA undercabinet & 6 & 2 & 4 & & & 12 \\
\hline \multicolumn{7}{|l|}{ Improvement in home appearance } \\
\hline Future B Homes kitchen \& dining & 2 & 2 & 2 & & & 6 \\
\hline Lane County HBA kitchen \& living & 5 & 2 & 4 & 1 & & 12 \\
\hline Lane County HBA undercabinet & 6 & 3 & 3 & & & 12 \\
\hline & & & & & & \\
\hline \multicolumn{7}{|l|}{ Improvement in home value } \\
\hline Future B Homes kitchen \& dining & 3 & 2 & 1 & & & 6 \\
\hline Lane County HBA kitchen \& living & 6 & 4 & 2 & & & 12 \\
\hline Lane County HBA undercabinet & 7 & 3 & 2 & & & 12 \\
\hline & & & & & & \\
\hline Fixture preference & New & & Old & & Total & \\
\hline Future B Homes kitchen \& dining & 4 & & 2 & & 6 & \\
\hline Lane County HBA kitchen \& living & 8 & & 4 & & 12 & \\
\hline Lane County HBA undercabinet & 8 & & 4 & & 12 & \\
\hline
\end{tabular}


E.4 


\section{Appendix F}

\section{Payback Calculations and Assumptions}





\section{Appendix F}

\section{Calculations and Assumptions}

Annual Operation Costs \& Savings Downlights:

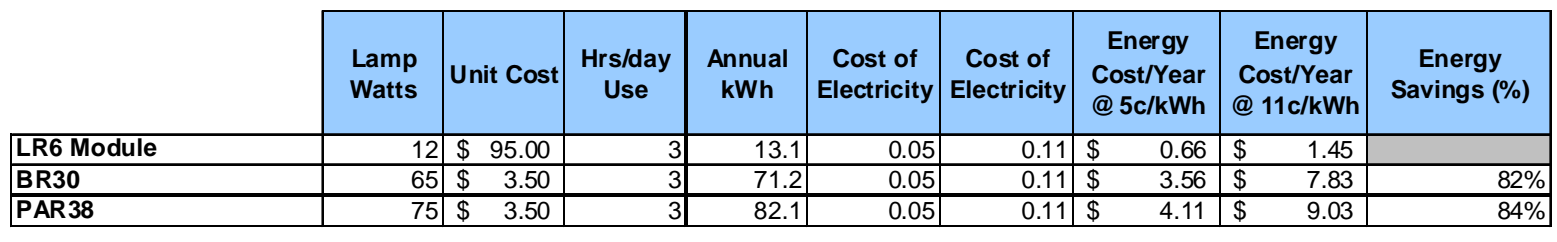

Payback Calculations Assumptions, Downlights:

Replacement lamp life @1050 hours, average cost \$3.50

LR6: life at 50,000 hours; LR6 “builder cost” of \$95

Average Eugene electricity cost: 5cents/kWh, national electricity cost: 11 cents/kWh;

\begin{tabular}{|c|c|c|c|c|c|c|c|c|c|c|c|c|c|}
\hline & $\begin{array}{l}\text { Lamp } \\
\text { Watts }\end{array}$ & Unit Cost & $\begin{array}{c}\text { Hrs/day } \\
\text { Use }\end{array}$ & $\begin{array}{l}\text { Annual } \\
\text { kWh }\end{array}$ & $\begin{array}{c}\text { Cost of } \\
\text { Electricity }\end{array}$ & $\begin{array}{c}\text { Cost of } \\
\text { Electricity }\end{array}$ & $\begin{array}{c}\text { Energy } \\
\text { Cost/Year } \\
@ 5 c / k W h\end{array}$ & $\begin{array}{c}\text { Energy } \\
\text { Cost/Year } \\
@ \text { 11c/kWh }\end{array}$ & $\begin{array}{l}\text { Replacement } \\
\text { lamp } \\
\text { costs/year }\end{array}$ & $\begin{array}{c}\text { Annual } \\
\text { Operating } \\
\text { Costs @ 5c } \\
\text { (elec + lamp) }\end{array}$ & $\begin{array}{c}\text { Annual } \\
\text { Operating } \\
\text { Costs @ 11c } \\
\text { (elec. + lamp) }\end{array}$ & $\begin{array}{c}\text { LEDs } \\
\text { Payback @ } \\
\text { 5c/kWh }\end{array}$ & $\begin{array}{c}\text { LEDs } \\
\text { Payback @ } \\
\text { 11c/kWh }\end{array}$ \\
\hline LED Module & 12 & $\begin{array}{|ll|}\$ 95.00 \\
\end{array}$ & 3 & 13.1 & 0.05 & 0.11 & 0.66 & 1.45 & & $\$ \quad 0.66$ & $\begin{array}{ll}\$ & 1.45 \\
\end{array}$ & & \\
\hline BR30 & 65 & $\begin{array}{|ll|}\$ 3.50 \\
\end{array}$ & 3 & 71.2 & 0.05 & 0.11 & 3.56 & 7.83 & 3.50 & 7.06 & 11.33 & 14.8 & 9.6 \\
\hline $\begin{array}{l}\text { PAR38 } \\
\end{array}$ & 75 & 3.50 & 3 & 82.1 & 0.05 & 0.11 & 4.11 & 9.03 & 3.50 & 7.61 & 12.53 & 13.7 & 8.6 \\
\hline
\end{tabular}

Annual Operation Costs \& Savings, Undercabinets:

\begin{tabular}{|c|c|c|c|c|c|c|c|c|c|c|c|}
\hline & $\begin{array}{l}\text { Lamp } \\
\text { Watts }\end{array}$ & Unit Cost & $\begin{array}{l}\text { Hrs/day } \\
\text { Use }\end{array}$ & $\begin{array}{c}\text { Annual } \\
\text { kWh }\end{array}$ & $\begin{array}{c}\text { Cost of } \\
\text { Electricity }\end{array}$ & $\begin{array}{c}\text { Cost of } \\
\text { Electricity }\end{array}$ & & $\begin{array}{l}\text { ergy } \\
\text { /Year } \\
\text { /kWh }\end{array}$ & & $\begin{array}{l}\text { rgy } \\
\text { Year } \\
\text { :kWh }\end{array}$ & $\begin{array}{c}\text { Energy } \\
\text { Savings (\%) }\end{array}$ \\
\hline eW Powercore LEDs & 10 & $\$ 140.00$ & 2 & 7.3 & 0.05 & 0.11 & $\$$ & 0.37 & $\$$ & 0.80 & \\
\hline CSL Halogen Low Level & 60 & $\$ 80.00$ & 2 & 43.8 & 0.05 & 0.11 & $\$$ & 2.19 & $\$$ & 4.82 & $83.3 \%$ \\
\hline CSL Halogen High Level & 105 & $\$ 80.00$ & 2 & 76.7 & 0.05 & 0.11 & $\$$ & 3.83 & $\$$ & 8.43 & $90.5 \%$ \\
\hline
\end{tabular}




\section{Payback Calculations Assumptions, Undercabinets:}

Replacement lamp life @2000 hours, average cost \$5.60 for 35w T4 G8 C 120v Halogen

eW: life at 50,000 hours; MSRP of \$140

Average Eugene electricity cost: 5cents/kWh, national electricity cost: 11 cents/kWh;

New Construction Case - 2 hours/day use:

\begin{tabular}{|c|c|c|c|c|c|c|c|c|c|c|c|c|c|c|}
\hline & $\begin{array}{l}\text { Lamp } \\
\text { Watts }\end{array}$ & Unit Cost & $\begin{array}{l}\text { Hrs/day } \\
\text { Use }\end{array}$ & $\begin{array}{c}\text { Annual } \\
\text { kWh }\end{array}$ & $\begin{array}{c}\text { Cost of } \\
\text { Electricity }\end{array}$ & $\begin{array}{c}\text { Cost of } \\
\text { Electricity }\end{array}$ & $\begin{array}{c}\text { Energy } \\
\text { Cost/Year } \\
@ 5 c / k W h\end{array}$ & $\begin{array}{c}\text { Energy } \\
\text { Cost/Year } \\
@ \text { 11c/kWh }\end{array}$ & $\begin{array}{l}\text { Replacement } \\
\text { lamp } \\
\text { costs/year }\end{array}$ & & $\begin{array}{l}\text { ual } \\
\text { ating } \\
@ 5 c \\
\text { lamp) }\end{array}$ & $\begin{array}{c}\text { Annual } \\
\text { Operating } \\
\text { Costs @ 11c } \\
\text { (elec. + lamp) }\end{array}$ & $\begin{array}{c}\text { LEDs } \\
\text { Payback @ } \\
\text { 5c/kWh }\end{array}$ & $\begin{array}{c}\text { LEDs } \\
\text { Payback @ } \\
\text { 11c/kWh }\end{array}$ \\
\hline & 1 & 140 & 2 & 7.3 & 0.05 & 0.11 & 0.37 & 0.80 & & $\$$ & 0.37 & $\$$ & & \\
\hline CSL Halogen Low Level & 60 & 80 & 2 & 43.8 & 0.05 & 0.11 & 2.19 & 4.82 & 6.12 & $\$$ & 8.31 & 10.94 & 7.6 & 5.9 \\
\hline CSL Halogen High Level & 105 & 80 & 2 & 76.7 & 0.05 & 0.11 & 3.83 & 8.43 & 6.12 & $\$$ & 9.95 & 14.55 & 6.3 & 4.4 \\
\hline
\end{tabular}

New Construction Case - 4 hours/day use:

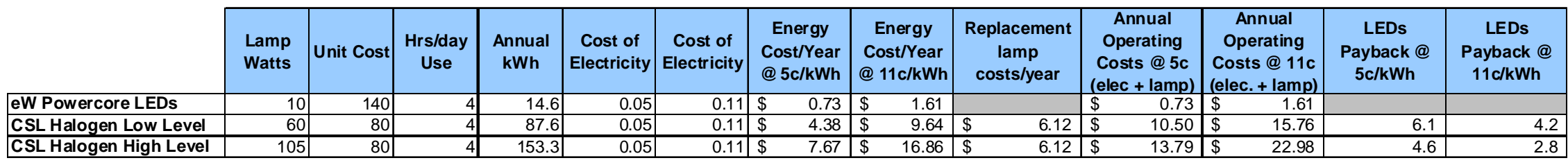

Retrofit Case - 4 hours/day use

\begin{tabular}{|c|c|c|c|c|c|c|c|c|c|c|c|c|c|c|}
\hline & $\begin{array}{l}\text { Lamp } \\
\text { Watts }\end{array}$ & Unit Cost & $\begin{array}{l}\text { Hrs/day } \\
\text { Use }\end{array}$ & $\begin{array}{c}\text { Annual } \\
\text { kWh }\end{array}$ & $\begin{array}{c}\text { Cost of } \\
\text { Electricity }\end{array}$ & \begin{tabular}{|c} 
Cost of \\
Electricity
\end{tabular} & $\begin{array}{c}\text { Energy } \\
\text { Cost/Year } \\
@ 5 c / k W h\end{array}$ & $\begin{array}{c}\text { Energy } \\
\text { Cost/Year } \\
@ \text { 11c/kWh }\end{array}$ & $\begin{array}{c}\text { Replacement } \\
\text { lamp } \\
\text { costs/year }\end{array}$ & & $\begin{array}{l}\text { lual } \\
\text { ating } \\
\text { @ 5c } \\
\text { lamp) }\end{array}$ & $\begin{array}{c}\text { Annual } \\
\text { Operating } \\
\text { Costs @ 11c } \\
\text { (elec. + lamp) }\end{array}$ & $\begin{array}{c}\text { LEDs } \\
\text { Payback @ } \\
\text { 5c/kWh }\end{array}$ & $\begin{array}{c}\text { LEDs } \\
\text { Payback @ } \\
\text { 11c/kWh }\end{array}$ \\
\hline eW Powercore LEDs & 10 & $\$ 140.00$ & 4 & 14.6 & 0.05 & 0.11 & 0.73 & 1.61 & & $\$$ & 0.73 & \begin{tabular}{ll|}
$\$$ & 1.61 \\
\end{tabular} & & \\
\hline CSL Halogen Low Level & 60 & $\$ 80.00$ & 4 & 87.6 & 0.05 & 0.11 & 4.38 & 9.64 & 6.12 & $\$$ & 10.50 & 15.76 & 14.3 & 9.9 \\
\hline CSL Halogen High Level & 105 & $\$ 80.00$ & 4 & 153.3 & 0.05 & 0.11 & 7.67 & 16.86 & 6.12 & $\$$ & 13.79 & 22.98 & 10.7 & 6.5 \\
\hline
\end{tabular}




\section{Appendix G}

\section{Simulations of the LR6 in Homes}





\section{Appendix G}

\section{Simulation of the LR6 in Homes}

Simulation Results for Future B Homes' Home

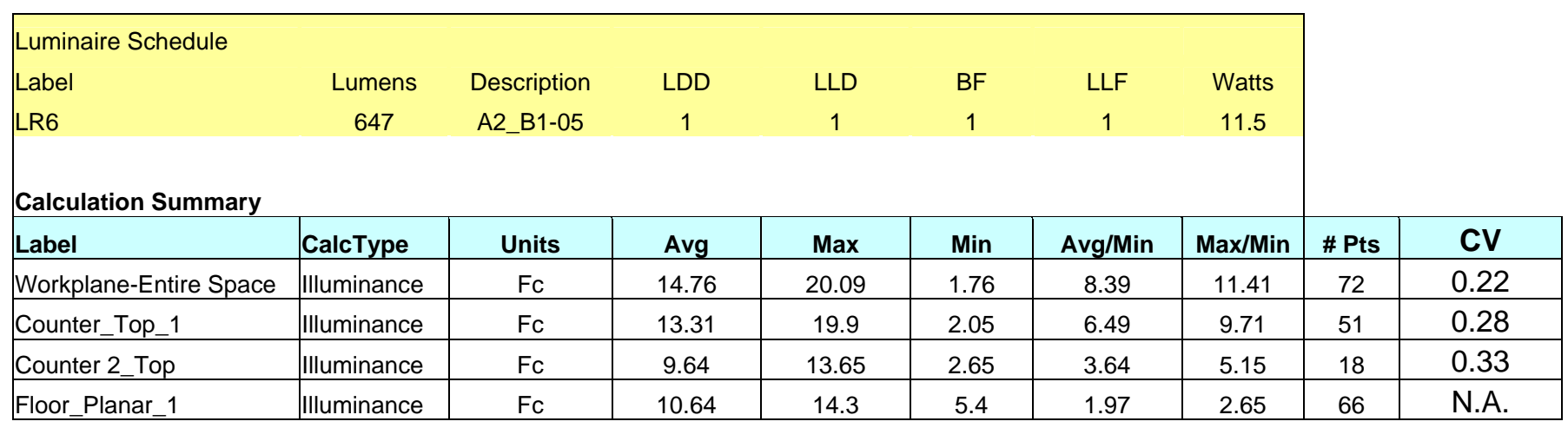

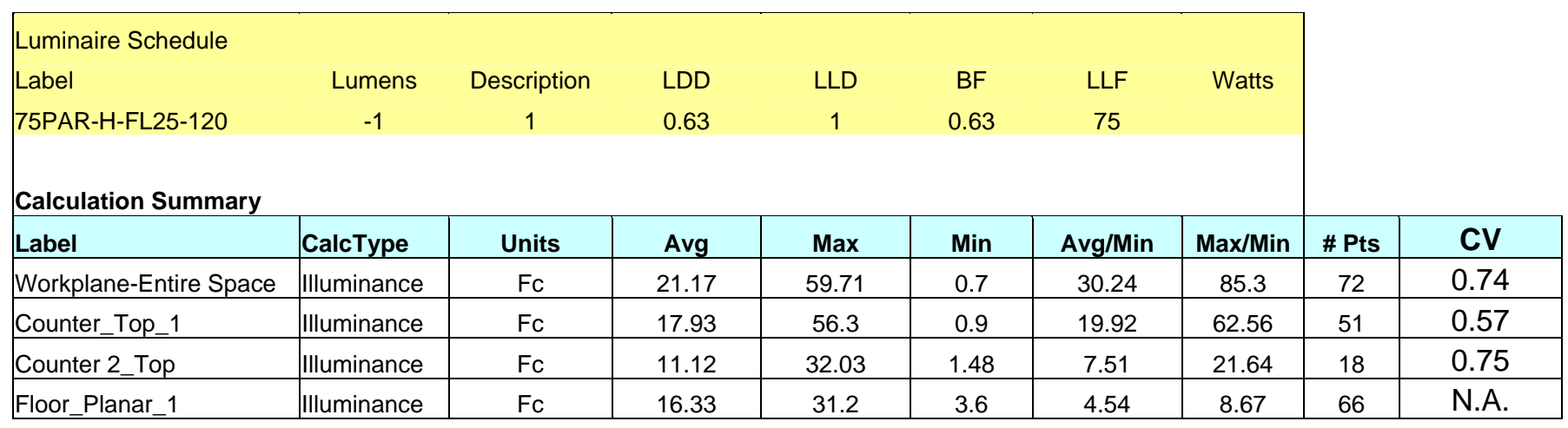

\begin{tabular}{|c|c|c|c|c|c|c|c|c|c|}
\hline \multicolumn{10}{|l|}{ Luminaire Schedule } \\
\hline Lightolier PAR38 & 1050 & B7780CLW & 1 & 1 & 1 & 1 & 75 & & \\
\hline \multicolumn{10}{|l|}{ Calculation Summary } \\
\hline Label & CalcType & Units & Avg & $\operatorname{Max}$ & Min & Avg/Min & Max/Min & \# Pts & CV \\
\hline Counter 2_Top & Illuminance & $\mathrm{Fc}$ & 13.93 & 34.06 & 1.09 & 12.78 & 31.25 & 18 & 0.7 \\
\hline Floor_Planar_1 & Illuminance & $\mathrm{Fc}$ & 18.45 & 29.7 & 5.1 & 3.62 & 5.82 & 66 & N.A. \\
\hline
\end{tabular}




\section{Simulation Results for HBA of Lane County's}

Home

\begin{tabular}{|c|c|c|c|c|c|c|c|}
\hline \multicolumn{8}{|l|}{ Luminaire Schedule } \\
\hline Label & Description & Lumens & LDD & LLD & $\mathrm{BF}$ & LLF & Watts \\
\hline LR6andLR6C & A2_B1-05 & 647 & 1 & 1 & 1 & 1 & 11.5 \\
\hline eW_Profile_Powercore & $523-000027-01$ & 275 & 1 & 1 & 1 & 1 & 10.1 \\
\hline \multicolumn{8}{|l|}{ Calculation Summary } \\
\hline Label & CalcType & Units & Avg & Max & Min & Avg/Min & Max/Min \\
\hline Kitchen Workplane & Illuminance & $\mathrm{FC}$ & 15.7 & 43.9 & 3.1 & \begin{tabular}{|r|}
5.06 \\
\end{tabular} & 14.16 \\
\hline Living Room Workplane & Illuminance & $\mathrm{FC}$ & 5.29 & 6.3 & 3.9 & 1.36 & 1.62 \\
\hline Living Room Floor_Planar & Illuminance & FC & 4.44 & 5.3 & 2.6 & 1.71 & 2.04 \\
\hline Kitchen Floor_Planar & Illuminance & Fc & 10.41 & 20.2 & 4.5 & 2.31 & 4.49 \\
\hline Counters_1_Counter Top & Illuminance & FC & 24.21 & 38.4 & 17.2 & 1.41 & 2.23 \\
\hline
\end{tabular}

\begin{tabular}{|c|c|c|c|c|c|c|c|}
\hline \multicolumn{8}{|l|}{ Luminaire Schedule } \\
\hline Label & Description & Lumens & LDD & LLD & BF & LLF & Watts \\
\hline 65W R Flood Lamp & & $-1 \quad 1$ & 0.625 & 1 & 0.625 & 0 & \\
\hline ITL57565 & LIH22 & 320 & 1 & 1 & 1 & 1 & 60 \\
\hline \multicolumn{8}{|l|}{ Calculation Summary } \\
\hline Label & CalcType & Units & Avg & $\operatorname{Max}$ & Min & Avg/Min & Max/Min \\
\hline Kitchen Workplane & Illuminance & Fc & 14.23 & 54.8 & 1.8 & 7.91 & 30.44 \\
\hline Living Room Workplane & Illuminance & Fc & 4.5 & 5.3 & 3.2 & 1.41 & 1.66 \\
\hline Living Room Floor_Planar & Illuminance & Fc & 3.8 & 4.7 & 2.1 & 1.81 & 2.24 \\
\hline Kitchen Floor_Planar & Illuminance & Fc & 8.98 & 20.1 & 3 & 2.99 & 6.7 \\
\hline Counters_1_Counter Top & Illuminance & Fc & 25.6 & 52.5 & 15 & 1.71 & 3.5 \\
\hline
\end{tabular}

\begin{tabular}{|llcccccc|}
\hline Luminaire Schedule & & & & & & & \\
Label & Description & Lumens & LDD & LLD & BF & LLF & Watts \\
ITL57565 & LIH22 & 320 & 1 & 1 & 1 & 1 & 60 \\
IC2-24B-65BR30 & IC2-24B-WH & 725 & 1 & 1 & 1 & 1 & 65.4
\end{tabular}

\section{Calculation Summary}

\begin{tabular}{|l|l|l|r|r|r|r|r|}
\hline Label & CalcType & Units & Avg & Max & Min & Avg/Min Max/Min \\
\hline Kitchen Workplane & Illuminance & FC & 16.35 & 53.7 & 1.1 & 14.86 & 48.82 \\
\hline Living Room Workplane & Illuminance & Fc & 6.07 & 7.5 & 4 & 1.52 & 1.88 \\
\hline Living Room Floor_Planar & Illuminance & FC & 5.14 & 6.6 & 2.7 & 1.9 & 2.44 \\
\hline Kitchen Floor_Planar & Illuminance & FC & 11.05 & 25.3 & 2.3 & 4.8 & 11 \\
\hline Counters_1_Counter Top & Illuminance & Fc & 28.69 & 52.3 & 17.7 & 1.62 & 2.95 \\
\hline
\end{tabular}

Luminaire Schedule Label

Description Lumens LDD LLD BF LLF Watts 


\begin{tabular}{|c|c|c|c|c|c|c|c|}
\hline ITL57565 & LIH22 & 320 & 1 & 1 & 1 & 1 & 60 \\
\hline $\begin{array}{l}\text { IC2-24W-65BR30 } \\
\text { Calculation Summary }\end{array}$ & IC2-24W-WH & 725 & 1 & 1 & 1 & 1 & 65 \\
\hline Label & CalcType & Units & Avg & Max & Min & Avg/Min & ax/Min \\
\hline Kitchen Workplane & Illuminance & Fc & 18.55 & 54.7 & 1.8 & 10.31 & 30.39 \\
\hline Living Room Workplane & Illuminance & Fc & 6.95 & 8.5 & 4.7 & 1.48 & 1.81 \\
\hline Living Room Floor_Planar & Illuminance & Fc & 5.89 & 7.5 & 3.1 & 1.9 & 2.42 \\
\hline Kitchen Floor_Planar & Illuminance & Fc & 12.63 & 27.9 & 3.2 & 3.95 & 8.72 \\
\hline Counters_1_Counter Top & Illuminance & $\mathrm{FC}$ & 31.23 & 53.4 & 20.7 & 1.51 & 2.58 \\
\hline
\end{tabular}

\begin{tabular}{|c|c|c|c|c|c|c|c|}
\hline \multicolumn{8}{|l|}{ Luminaire Schedule } \\
\hline Label & Description & Lumens & LDD & LLD & $\mathrm{BF}$ & LLF & Watts \\
\hline ITL57565 & LIH22 & 320 & 1 & 1 & 1 & 1 & 60 \\
\hline IC2-27C-65BR30 & IC2-27C-WH & 725 & 1 & 1 & 1 & 1 & 65 \\
\hline \multicolumn{8}{|l|}{ Calculation Summary } \\
\hline Label & CalcType & Units & Avg & $\operatorname{Max}$ & Min & Avg/Min I & Max/Min \\
\hline Kitchen Workplane & Illuminance & Fc & \begin{tabular}{|l}
20.3 \\
\end{tabular} & \begin{tabular}{l|l}
3 & 54.2
\end{tabular} & 1.4 & 14.5 & 38.71 \\
\hline Living Room Workplane & Illuminance & $F c$ & 8.39 & 10.8 & 5.7 & 1.47 & 1.89 \\
\hline Living Room Floor_Planar & Illuminance & Fc & 7.14 & 9.1 & 3.6 & 1.98 & 2.53 \\
\hline Kitchen Floor_Planar & Illuminance & FC & 14.26 & 30.5 & 2.8 & 5.09 & 10.89 \\
\hline Counters_1_Counter Top & Illuminance & Fc & 33.84 & 53.4 & 21.8 & 1.55 & 2.45 \\
\hline
\end{tabular}

\begin{tabular}{|c|c|c|c|c|c|c|c|}
\hline $\begin{array}{l}\text { Luminaire Schedule } \\
\text { Label }\end{array}$ & Description & Lumens & LDD & LLD & BF & LLF & Watts \\
\hline ITL57565 & $\mathrm{LIH} 22$ & 320 & 1 & 1 & 1 & 1 & 60 \\
\hline IC2-250-65BR30 & IC2-250-WH & 725 & 1 & 1 & 1 & 1 & 65.1 \\
\hline \multicolumn{8}{|l|}{ Calculation Summary } \\
\hline Label & CalcType & Units & Avg & Max & Min & Avg/Min $M$ & Max/Min \\
\hline Kitchen Workplane & Illuminance & FC & 19.21 & 56 & 2.3 & 8.35 & 24.35 \\
\hline Living Room Workplane & Illuminance & Fc & 6.81 & 8.1 & 4.8 & 1.42 & 1.69 \\
\hline Living Room Floor_Planar & Illuminance & $\mathrm{Fc}$ & 5.73 & 7 & 3.2 & 1.79 & 2.19 \\
\hline Kitchen Floor_Planar & Illuminance & Fc & 12.87 & 27.3 & 4.3 & 2.99 & 6.35 \\
\hline Counters_1_Counter Top & Illuminance & Fc & 31.78 & 54.4 & 21.9 & 1.45 & 2.48 \\
\hline
\end{tabular}


G.4 